\title{
"A RELAÇÃO DA CONCENTRAÇÃO DE CHUMBO NOS SANGUES MATERNO E DO CORDÃO UMBILICAL"
}

\author{
Luz Estela Zentner Alva
}

Tese apresentada ao Departamento de Nutrição da Faculdade de Saúde Pública da Universidade de São Paulo para a obtenção do grau de Doutor em Saúde Pública.

Área de concentração: Nutrição.

Orientadora: Prof ${ }^{a}$. Dr ${ }^{\mathrm{a}}$. Patrícia Helen de Carvalho Rondó 


\section{DEDICATÓRIA}

Dedico este trabalho a...

Meus queridos pais: Juan Francisco e Nélida Victória, pelo amor, exemplo e confiança....

Meus irmãos: Juan Francisco Jr e César Enrique, pelo carinho e força para seguir sempre a frente...

Minha sobrinha: Claudia Lizbeth Zentner fonte de inspiração...

Meu namorado, mas sobre todo um amigo muito especial: José Domingo, pela paciência, amor e palavras de ânimo sempre no momento exato...

Todas as parturientes e recém-nascidos, que participaram e fizeram possivel a culminação deste trabalho 


\section{AGRADECIMENTOS}

A concretização deste trabalho foi possível graças à colaboração de várias pessoas e. Instituições, às quais registro aqui os meus sinceros agradecimentos:

$\grave{A}$ Deus pela vida.

À Profa. Dra. Patrícia Helen de Carvalho Rondó, minha orientadora, pela dedicação e apoio constante na concretização deste trabalho, assim como pela sua amizade.

Ao Prof. Dr. Eduardo Juan Troster, pelas valiosas sugestões concedidas para a elaboração deste trabalho.

Ao Prof. Dr. Henrique Vicente Della Rosa, pela contribuição e apoio incondicional.

Ao Prof. Dr. Carlos Celso do Amaral e Silva, pela colaboração e disposição para a conclusão deste trabalho.

À Profa. Dra. Maria do Rosário Dias de Oliveira Latorre, pela imprescindível ajuda nas análises estatísticas.

À Profa. Dra. Elvira Maria Guerra-Shinohara, pela amizade e pelo auxílio para a realização deste trabalho.

Ao Sr. Bruce Weiner representante do laboratório dos equipamentos AndCare Inc. em Durham, NC, Estados Unidos, pela doação dos 3 kits para a realização das dosagens das amostras de chumbo através do aparelho LeadCare. 
Ao Dr. Sebastião Dias Pereira, Secretário de Saúde do município de Santo Amaro da Purificação e ao Dr. Edilson de Almeida Garrido, Diretor do Hospital Maternidade de Santo Amaro da Purificação, pelo apoio incondicional para a realização deste trabalho.

Aos médicos, enfermeiras e auxiliares de enfermagem do "Hospital Maternidade de Santo Amaro da Purificação", pela viabilização da coleta de dados neste hospital.

Aos funcionários do Instituto "Adolfo Lutz", pela colaboração nas dosagens das amostras de chumbo, em especial aos colegas Alice Sakuma, María Cristina Duran, Isaura Akemi Okada e María de Fátima Henriques Carvalho.

Aos funcionários do Departamento de Nutrição da Faculdade de Saúde Pública, em especial à Elizabethe Desbaldo dos Santos, Alessandra Fructuoso e Regilene Maria de Jesus, pela atenção e colaboração.

Aos funcionários da Comissão de Pós Graduação, em especial à Márcia e Graça pelo apoio e a disposição sempre para ajudar.

Aos funcionários da biblioteca da Faculdade de Saúde Pública, em especial à Maria Lúcia de Faria Ferraz, pela revisão das referências bibliográficas.

À Coordenação de Aperfeiçoamento de Pessoal de Nivel Superior (CAPES), pelo auxílio parcial concedido através da bolsa emergencial de doutorado. 
Ás amigas, Karla Hernández, Mónica Montenegro, Ixis Itaymes, Zoraida Fernández, Eliana Lavalle, Rosanilda Chávez, pelos laços de amizade e pela força ao encontrarmos longe de nossas famílias e países. Muito Obrigada!

Às amigas (os) brasileiras (os) que conheci durante minha estadia neste maravilhoso país. Impossivel mencionar todas (os) elas (es). 


\section{RESUMO}

Zentner LE. A relação da concentração de chumbo nos sangues materno e do cordão umbilical. São Paulo, 2003. [Tese apresentada à Faculdade de Saúde Pública da USP].

Objetivos. 1.Comparar as médias dos niveis de chumbo das parturientes, segundo a distância entre o local de residência e a fonte de contaminação de chumbo; 2.determinar a relação entre os niveis de chumbo de parturientes e seus respectivos recém nascidos, analisadas através de dois métodos; 3.verificar os fatores preditores dos elevados niveis de chumbo nas parturientes; 4.verificar os fatores preditores dos elevados niveis de chumbo nos recém-nascidos. Materiais e Métodos. Foram estudados 50 pares de parturientes e recém nascidos em um hospital matemidade localizado no município de Santo Amaro, Bahia. Os dados referentes à situação demográfica, sócio econômica, estado nutricional e história obstétrica foram obtidos através de um questionário elaborado para este estudo. $O$ consumo alimentar foi estimado através de questionário de freqüência alimentar para verificar o consumo de cálcio, ferro e vitamina $C$, nutrientes que podem interagir com o chumbo. Amostras de sangue venoso das parturientes e do cordão umbilical foram utilizadas para a determinação dos niveis de chumbo e de hemoglobina. Estas amostras foram analisadas através dos métodos de espectrofotometria e eletroquimica- "LeadCare". No caso da hemoglobina utilizouse o aparelho HemoCue. Para a comparação das médias de chumbo das parturientes que residiam perto, a uma distância média ou longe da fonte de contaminação, utilizou-se o Teste t-Student. A relação entre os niveis de chumbo das parturientes e seus respectivos recém-nascidos foi analisada através do coeficiente de correlação de Pearson. Para analisar a associação entre as diversas variáveis investigadas neste estudo com relação à contaminação de chumbo foi realizada análise de regressão linear múltipla. Resultados. Verificou-se que as médias dos niveis de chumbo no sangue das parturientes que moram perto da fonte de contaminação foram maiores que as médias dos niveis sangüíneos de chumbo no sangue das parturientes que moram à distância média ou longe. Observou-se uma boa correlação entre os niveis sangüineos de chumbo das parturientes e seus respectivos recém-nascidos, independente do método utilizado. O melhor modelo de predição para altos niveis de chumbo no sangue de 
parturientes incluiu o peso, a hemoglobina e o consumo de cálcio. O melhor modelo de predição para altos niveis de chumbo no sangue de recém-nascidos incluiu o comprimento e o peso. Conclusōes. A contaminação por chumbo é um sério problema na gestação, considerando-se que o chumbo atravessa a placenta, provavelmente influenciando o crescimento do feto. Sugere-se a implementação de programas de suplementação com ferro, para prevenção da deficiência de ferro, e um aumento no consumo de cálcio, nas populações de maior risco de contaminação por chumbo.

Descritores: chumbo; parturiente; cordão umbilical; recém nascido. 


\section{SUMMARY}

Zentner LE. Relationship between lead concentrations in maternal blood and umbilical cord blood. São Paulo, 2003. [Tese apresentada à Faculdade de Saúde Pública da USP].

Objectives. 1.Compare the mean blood levels of lead in pregnant women according to the distance of their houses from the lead industry; 2.determine the relationship between mean blood levels of lead in pregnant women and respective newbom babies utilising spectrophotometry and electrochemical-"LeadCare"; 3.assess the best predictors for the high blood levels of lead in pregnant women; 4.assess the best predictors for the high blood levels of lead in newborn babies. Materials and Methods. Fifty (50) pairs of pregnant women and respective newborn babies were selected from a maternity hospital in Santo Amaro city, Northeast Brazil. Information regarding demography, socioeconomic status, nutritional status and obstetric history were obtained by a standardized questionnaire. Food intake was estimated using a food frequency questionnaire to verify calcium, iron and vitamin $C$ intakes, nutrients that may interact with lead. Venous blood samples were taken from pregnant women and from umbilical cord to determine lead and hemoglobin levels in serum. Serum lead was determined by spectrophotometry and electrochemical-"LeadCare". Serum hemoglobin was determined by HemoCue. To compare the mean blood levels of lead in pregnant women according to the distance of their houses from the lead industry the Student-t test was utilized. The relationship between the blood lead levels in pregnant women and their respective newborn babies was determined by Pearson's coeficient. A multivariate linear regression model was used to analyze the association of several variables investigated in the study, in relation to lead contamination. Results. The mean blood levels of lead in pregnant women living near a lead industry was higher than the mean blood levels of lead in pregnant women living far from the source of contamination. There was a strong correlation between the levels of lead in pregnant women and newborn babies utilising either spectrophotometry or electrochemical-“LeadCare”. The best predictor model for high blood levels of lead in pregnant women included weigth, hemoglobin and calcium intake. The best predictor model for high blood levels of lead in newborn babies included length and weigth. Conclusions. Lead contamination is a serious problem in pregnancy, considering that lead seems to cross the placenta, probably 
influencing fetal growth. We suggest the implementation of iron supplementation programmes, to prevent and to treat iron deficiency, and also an increase in calcium intake in populations at risk for lead contamination.

Descriptors: lead; pregnant women; umbilical cord; newborn babies. 


\section{INDICE}

Página

1.INTRODUÇÃO

1.1. PARÂMETROS PARA AVALIAÇÃO DA CONTAMINAÇÃO POR CHUMBOO …......................

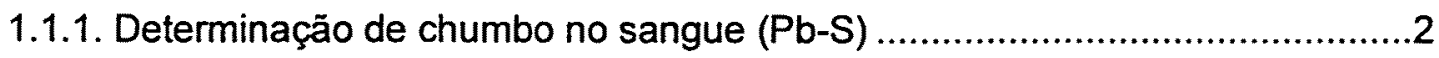

1.1.2. Determinação de chumbo ( $P b-U$ ) e do ácido delta-aminolevulinico (ALA-U)

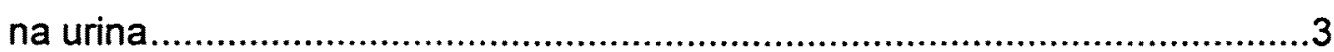

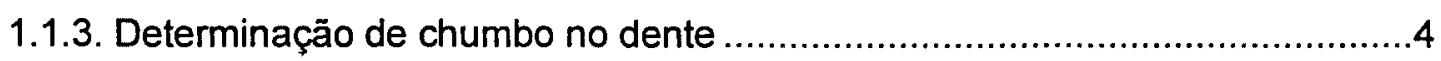

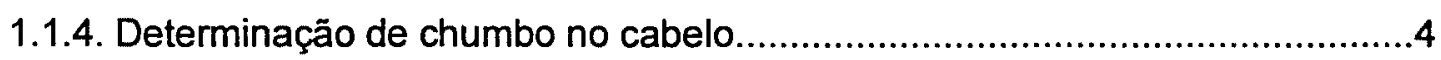

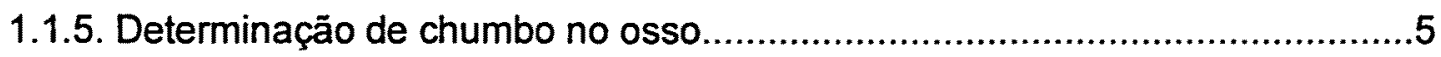

1.2. CONTAMINAÇÃO POR CHUMBO NO BINÔMIO MÃE/RECÉM-NASCIDO ...........................

1.3. RELAÇÃO DO METABOLISMO DO CHUMBO COM ALGUNS MICRONUTRIENTES .............10

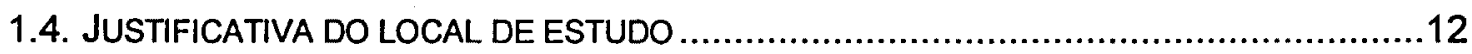

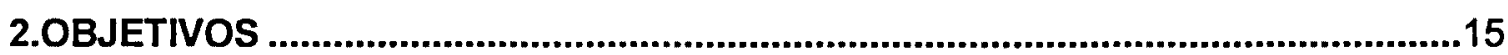

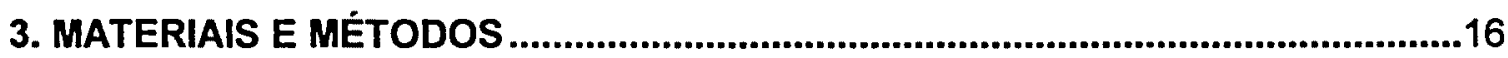

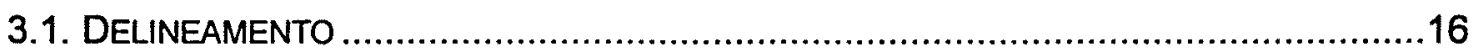

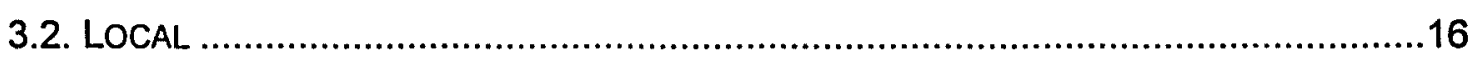

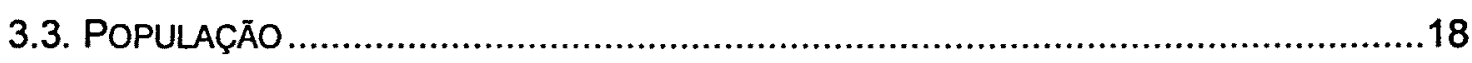

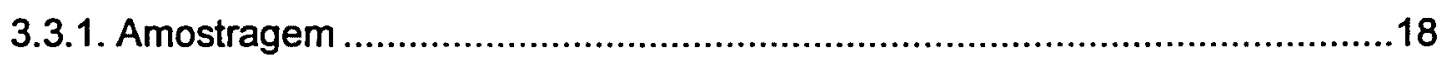

3.4. COLETA DE DADOS ANTROPOMÉTRICOS E DEMOGRAFICOS ..................................18

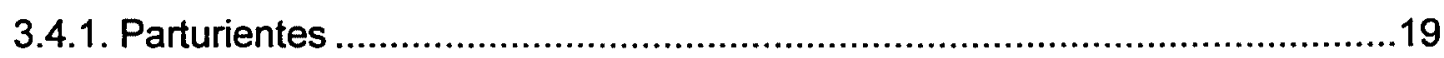

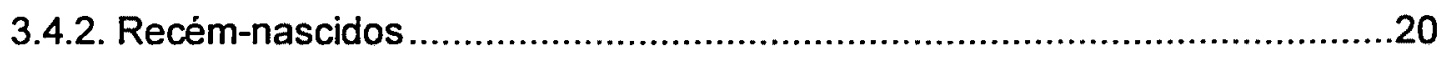

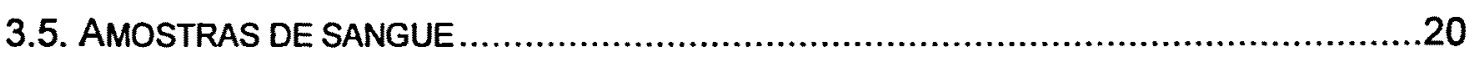

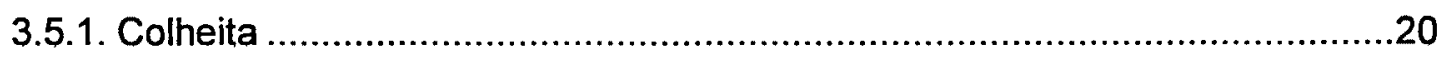

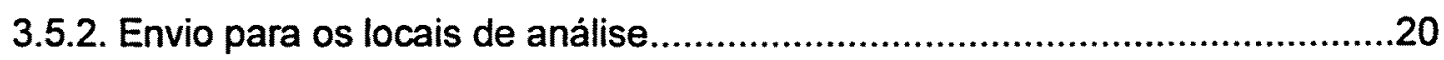

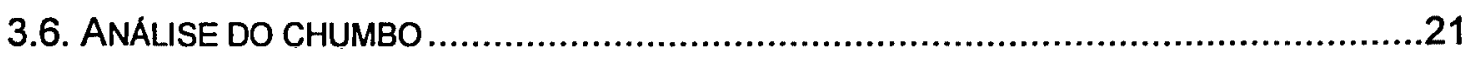

3.6.1. Espectrofotometria de absorção atômica com forno de grafite (AA-FG).......21

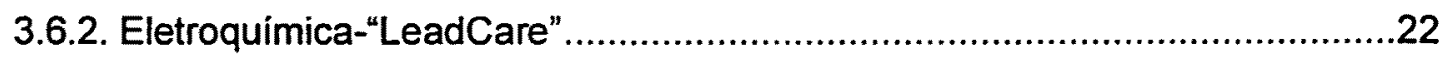

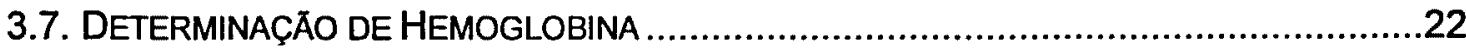




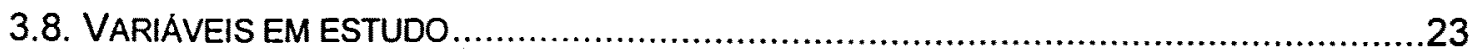

3.8.1.Variáveis para caracterização das parturientes: .......................................23

3.8.2. Variáveis para caracterização do recém-nascido: .....................................23

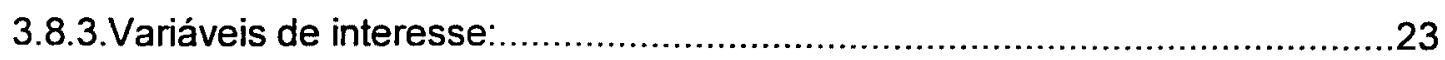

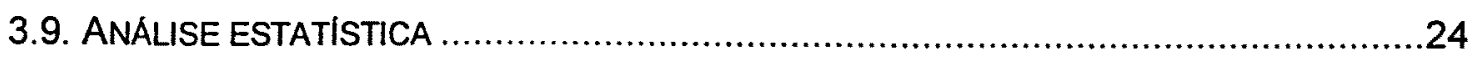

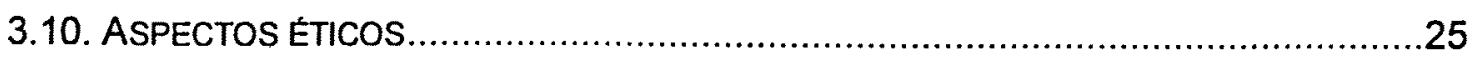

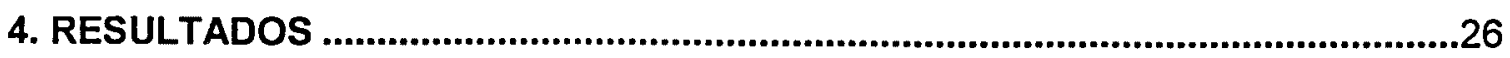

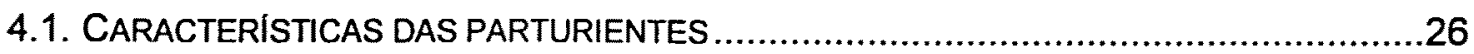

4.1.1. Caracteristicas demográficas e sócio-econômicas ..................................26

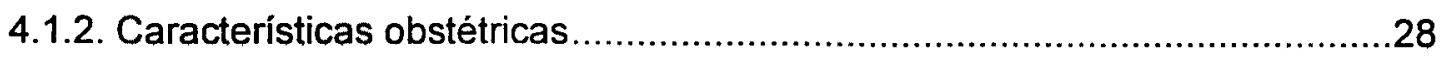

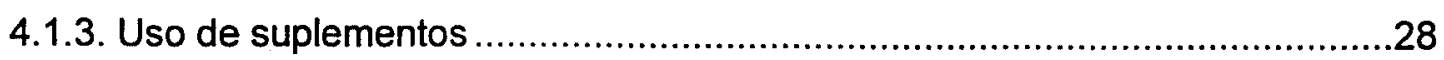

4.1.4. Caracteristicas antropométricas .......................................................28

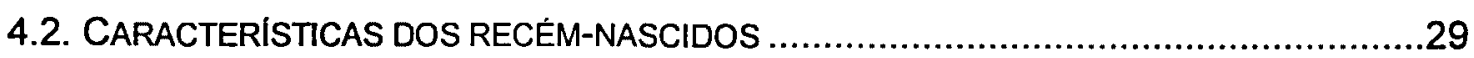

4.3. NIVEIS SANGÜINEOS DE CHUMBO EM PARTURIENTES E RECÉM-NASCIDOS (CORDÃO

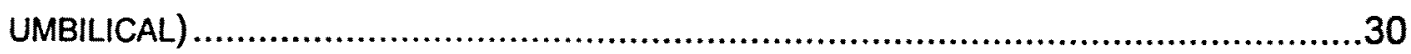

4.3.1. Niveis de chumbo das parturientes em relação ao foco de contaminação ...30

4.3.2. Relação dos niveis de chumbo das parturientes e seus respectivos recém-

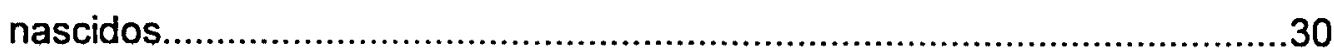

4.3.3. Modelos de regressão da parturiente...................................................32

4.3.4. Modelos de regressão do recém-nascido .............................................34

5. DISCUSSÃO

5.1. CARACTERISTICAS DAS PARTURIENTES ....................................................36

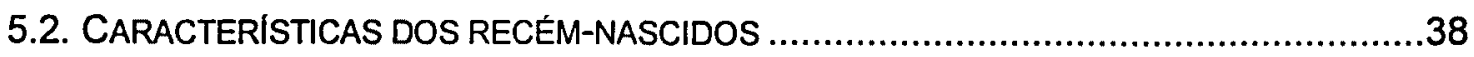

5.3. NIVEIS SANGÜÍNEOS DE CHUMBO EM PARTURIENTES E RECÉM-NASCIDOS (CORDÃO

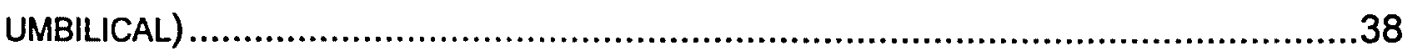

5.3.1. Niveis de chumbo das parturientes em relação ao foco de contaminação...39

5.3.2. Relação dos niveis de chumbo das parturientes e seus respectivos recémnascidos

5.3.3. Associação entre os niveis sangüineos de chumbo e peso, hemoglobina e consumo de cálcio das parturientes 
5.3.4. Associação entre os niveis sangüineos de chumbo e comprimento e peso dos recém-nascidos .....................................................................45

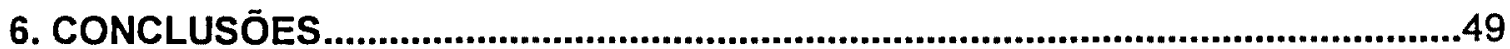

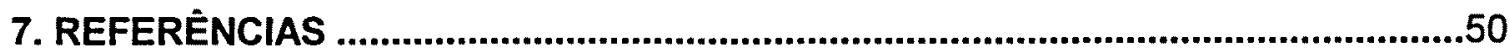

RESUMO

SUMMARY

ANEXOS 


\section{Introdução}

Em muitos países da América, a contaminação por chumbo apresenta uma prevalência considerável, podendo acarretar alterações nos sistemas renal, nervoso e hematopoiético (Fergusson, 1990; Needleman, 1993). A gravidade da presença do chumbo no organismo depende do grau de exposição, absorção e excreção (Barry et. al., 1970; ONU, 1979).

As principais fontes contaminadoras de chumbo são as minerações, as indústrias manipuladoras de chumbo, a gasolina adicionada de chumbo tetraetílico, pigmentos (principalmente de tintas), soldaduras de latas de alimentos, fabricação e uso de louça vitrificada para utilização domiciliar (somando-se ao tipo de cerâmica e acidez do alimento) (Rothenberg et. al., 1989).

Embora os problemas de saúde relacionados ao chumbo tenham sido observados primeiramente em populaçōes adultas expostas ocupacionalmente à altas concentrações deste metal (Rhainds et. al., 1993), também foram observados danos neurológicos expressos através de retardo no desenvolvimento psicomotor em crianças, assim como baixo peso ao nascimento (Guidi et. al., 1992; Lagerkvist et al., 1996a). Needleman et. al. (1990) concluíram, depois de um estudo tipo coorte de duração de 11 anos, que até mesmo a exposição à baixos niveis de chumbo em crianças, está associado com um déficit neurocognitivo que persiste até a adolescência.

Mulheres contaminadas por chumbo, durante a infância, podem depositar este metal nos ossos, e posteriormente mobilizalo para a corrente sangüínea na gravidez e o aleitamento, com efeitos tóxicos para o próprio organismo e, principalmente, para o recém-nascido. Existem estudos que têm documentado amplamente a facilidade com que o chumbo atravessa a barreira placentária, representando um sério problema para o feto (Goldman et. el., 1993; Goyer, 1997). A vida intra-uterina caracteriza-se como sendo o momento mais sensivel do desenvolvimento humano. Por isto, considera-se importante estudar os efeitos tóxicos produzidos pelo chumbo em neonatos (Raghunath et. al., 2000). 


\subsection{Parâmetros para avaliação da contaminação por chumboo}

Existem diversos parâmetros hematológicos e bioquimicos que refletem a contaminação por chumbo. As determinações de chumbo podem ser feitas em sangue, urina, dente, cabelo e osso.

\subsubsection{Determinação de chumbo no sangue ( $\mathrm{Pb}-\mathrm{S})$}

O nivel de chumbo no sangue é a ferramenta mais valiosa para a monitoração biológica, uma vez que a concentração de chumbo no sangue é afetada pela absorção recente.

Os niveis sangüíneos de chumbo aceitáveis para adultos, até inicio da década de 90 , eram fixados em $25 \mu \mathrm{g} / \mathrm{dL}$. No entanto, observou-se que crianças e gestantes são mais sensíveis à esse metal, e conseqüentemente, mais susceptíveis a riscos do que outros indivíduos (Fergusson, 1990). Portanto, os niveis de exposição desse elemento foram determinados separadamente para adultos e crianças. A maioria dos paises ocidentais desenvolvidos adotaram $15 \mu \mathrm{g} / \mathrm{dL}$ como limite de segurança para niveis sangüineos em crianças (Needleman, 1993). Em 1991, baseados em estudos onde se observou que os niveis sangüineos de chumbo entre $10-25 \mu \mathrm{g} / \mathrm{dL}$ eram responsáveis pelo aparecimento de alterações do sistema nervoso central, o "Centers for Disease Control"- CDC, alterou o limite de segurança dos níveis sangüíneos de chumbo de $\leq 25 \mu \mathrm{g} / \mathrm{dL}$ para $\leq 10 \mu \mathrm{g} / \mathrm{dL}$ (CDC, 1996).

Outra maneira de se detectar a presença de chumbo é por meio do nível de protoporfirina nos eritrócitos, por método de fluorescência, que determina diretamente a zinco-protoporfirina (ZPP), a qual representa cerca de $95 \%$ da protoporfirina total dos eritrócitos. Para a realização deste procedimento é necessário aproximadamente $20 \mu \mathrm{l}$ de sangue. Para esta análise são considerados anormais os valores $>60 \mu \mathrm{mol} / \mathrm{mol}$ de heme, que é o valor de referência para adultos, uma vez que não estão definidos pontos de corte deste parâmetro para crianças (AVIV, 1998). 
A monitoração biológica da exposição ao chumbo pode ser realizada através da avaliação da atividade da enzima $\delta$-aminolevulínico desidratase ( $\delta$-ALA-D), a qual se encontra diminuída na presença de chumbo no organismo. A elevação dos níveis do ácido $\delta$-aminolevulínico devido a inibição da enzima $\delta$-ALA-D é um dos principais mecanismos neurotóxicos na contaminação por chumbo (Oga, 2003). A atividade dessa enzima é determinada no sangue nas primeiras 24 horas após a colheita, usando o European Standardized Method (Berlin e Schaller, 1974).

\subsubsection{Determinação de chumbo ( $\mathrm{Pb}-\mathrm{U})$ e do ácido delta-aminolevulínico (ALA-U) na urina}

Se for observada, em individuos expostos, uma taxa elevada de eliminação do chumbo, isso constitui-se numa indicação de uma absorção excessiva do chumbo. No entanto, uma taxa normal de eliminação não nos revelará a possibilidade de uma absorção excessiva. As concentrações de $\mathrm{Pb}-\mathrm{U}$ são mais variáveis do que aquelas de $\mathrm{Pb}-\mathrm{S}$ e, conseqüentemente acima da qual existiria um risco de intoxicação muito embora esses valores estejam citados na literatura (Oga, 2003).

A melhor conduta para controle, neste caso, consiste em comparar os valores de chumbo na urina para cada individuo exposto, com os valores obtidos anteriormente nas mesmas condições. Quando ocorrer uma elevação da plumburia $(\mathrm{Pb}-\mathrm{U})$ além da média dos resultados precedentes, deve-se suspeitar de uma exposição excessiva (Oga, 2003).

A determinação de ALA-U vem sendo utilizada há longo tempo como uma medida do efeito biológico do chumbo. Em indivíduos ocupacionalmente expostos foi verificado que o logaritmo da concentração de ALA-U aumenta linearmente com os valores de $\mathrm{Pb}-\mathrm{S}$ a partir de $40 \mu \mathrm{g} \mathrm{Pb} / 100 \mathrm{ml}$ de sangue. Esse teste apresenta uma boa especificidade na exposição ocupacional ao chumbo. Nos indivíduos recentemente expostos, a ALA-U eleva-se após um período de latência de cerca de 2 semanas. Com a interrupção da exposição a excreção volta aos valores normais em um prazo semelhante. Valores elevados de ALA-U podem ser encontrados também em 
individuos portadores de porfiria aguda e certas doenças hepáticas (Oga, 2003). Para ser utilizado este indicador, a concentração de ALA-U deve ser corrigida pelas variações no fluxo urinário, densidade da urina e horário da colheita, tomando-se a concentração de creatinina como padrão interno (Schutz e Skerfving, 1976; Manton e cook, 1984).

\subsubsection{Determinação de chumbo no dente}

Esse parâmetro tem sido usado como índice de exposição ao chumbo, especialmente nos dentes de leite de crianças. Existe uma correlação baixa entre niveis de chumbo em sangue e dente, provavelmente devido à variação considerável do nivel de chumbo que existe em um mesmo dente. Pode-se encontrar diferentes niveis de chumbo entre o esmalte e dentinas primária e secundária de uma mesma pessoa, dependendo da estrutura analisada. A despeito desta e de outras limitações, os dentes podem ser usados como amostra biológica que permite avaliar uma exposição integrada, incluindo a fase pré-natal e início da extra uterina, em grupos de individuos (Moller et. al., 1982).

\subsubsection{Determinação de chumbo no cabelo}

O chumbo é incorporado no cabelo durante o seu crescimento. Os niveis de chumbo aumentados no cabelo, detectados próximo a raiz, podem ser observados algumas semanas depois da exposição. A cronologia da exposição ao chumbo é refletida no perfil de concentrações ao longo do fio (Rabinowitz et. al., 1976). No entanto, o chumbo exógeno da poeira pode se constituir em contaminação difícil de ser distinguida do chumbo endógeno, incorporado durante o crescimento do cabelo. Devido a essas dificuldades, a determinação dos niveis de chumbo no cabelo tem uso cauteloso e limitado, a despeito das vantagens óbvias em termos de facilidade de amostragem, assim como de estocagem (Raymundo, 1981; Thatcher et. al., 1982; Carvalho et. al., 1983). 


\subsubsection{Determinação de chumbo no osso}

É possivel utilizar-se a determinação de chumbo no osso como indicador biológico de exposição remota. As amostras podem ser obtidas por biópsia, o que normalmente não é prático. Pode-se também determinar o chumbo no osso "in vivo", com fluorescência de raio $x$. As medidas podem ser efetuadas nos ossos digitais (Ahlgren et. al., 1980; Christoffersson et. al., 1984) e tíbia (Somervaille et. al., 1980; Wedeen et. al., 1995), com exposição de meia hora, à pequena dose de radiação.

Entre os diversos parâmetros para avaliação da contaminação por chumbo, o nivel de chumbo no sangue é o indicador mais utilizado. Os níveis de chumbo no sangue refletem a exposição recente, sendo que a exposição crônica a esse metal pesado deve ser avaliada pelo depósito de chumbo nos ossos. Portanto, é necessário considerar-se esse fenômeno em individuos que sofreram exposição pregressas a esse metal pesado, de tal maneira que seja possivel proteger a saúde desta população (Cordeiro et. al., 1996; Aguilar-Madrid et. al., 1999).

\subsection{Contaminação por chumbo no binômio mãe/recém-nascido}

Montoya et. al. (1981) analisaram os niveis de chumbo no sangue do cordão umbilical de recém nascidos, assim como no sangue materno. Os valores médios obtidos para 405 mulheres residentes nas áreas central e sul da cidade do México foram de $20,30 \mu \mathrm{g} / \mathrm{dL}( \pm 5,90 \mu \mathrm{g} / \mathrm{dL})$ no sangue materno e $13,57 \mu \mathrm{g} / \mathrm{dL}( \pm 5,25 \mu \mathrm{g} / \mathrm{dL})$ no cordão umbilical, concluindo-se que provavelmente a contaminação de chumbo nesta cidade se deve a gasolina dos veiculos automotores, cujo efeito contamina o ambiente em geral.

Outros autores, como Ong et. al. (1985), determinaram o nivel de chumbo no sangue materno e do cordão umbilical de parturientes que não foram ocupacionalmente expostas ao chumbo. Neste estudo, as médias do nivel de chumbo encontradas no sangue e cordão umbilical foram de $14,5 \mu \mathrm{g} / \mathrm{dL}$ e $11,4 \mu \mathrm{g} / \mathrm{dL}$, 
respectivamente. Uma correlação significativa foi observada entre os niveis no sangue materno e do cordão umbilical $(r=0,63 ; p<0,001)$.

Korpela et. al. (1986) estudaram os niveis de chumbo e cádmio nos sangues materno e do cordão umbilical em 19 parturientes entre 17 e 42 anos de idade. A média do nível de chumbo no sangue materno foi de $4,04 \mu \mathrm{g} / \mathrm{dL}$ e no cordão umbilical foi de $3,71 \mu \mathrm{g} / \mathrm{dL}$, mostrando uma correlação significativa entre ambos $(r=0,77 ; p<$ $0,001)$.

Troster (1986) avaliou a plumbemia de 43 parturientes e seus respectivos recém-nascidos no período de janeiro de 1984 a maio de 1985 no Berçário do Hospital das Clinicas de São Paulo, observando uma boa correlação $(r=0,68)$ entre a plumbemia materna e a neonatal, mostrando que há uma passagem através da placenta.

Graziano et. al. (1990) compararam na lugoslávia 602 gestantes da cidade de Mitrovica com 900 gestantes da cidade de Pristina durante o segundo trimestre da gestação, observando-se uma média geométrica de chumbo no sangue matemo de $17,1 \mu \mathrm{g} / \mathrm{dL}$ em Mitrovica contra 5,1 $\mathrm{g} / \mathrm{dL}$ em Pristina. Concluiu-se que o fator preditivo para tal achado foi a distância do foco de contaminação com o local de moradia, assim como o fato do marido da gestante trabalhar em uma industria metalúrgica de chumbo.

Rhainds et. al. (1993) observaram numa população de 823 parturientes em dois hospitais da cidade de Quebec (Canadá), niveis médios de chumbo no cordão umbilical equivalentes a $2,0 \mu \mathrm{g} / \mathrm{dL}$. A média mais elevada de chumbo era a da região urbana $(9,4 \%)$ quando comparada com a suburbana $(2,6 \%)$ e rural $(3,1 \%)$. Neste estudo concluíram que as características da residência destas parturientes foram os melhores indicadores de exposição à contaminação ao chumbo que o local de residência.

Baranowska (1995) avaliou o nivel de chumbo e cádmio nos sangues materno, da placenta e do cordão umbilical, encontrando $7,25 \mu \mathrm{g} / \mathrm{dL}$ de chumbo e $0,4 \mu \mathrm{g} / \mathrm{dL}$ de 
cádmio no sangue materno; $0,50 \mu \mathrm{g} / \mathrm{dL}$ de chumbo e $0,11 \mu \mathrm{g} / \mathrm{dL}$ de cádmio na placenta e $3,83 \mu \mathrm{g} / \mathrm{dL}$ de chumbo e $0,1 \mu \mathrm{g} / \mathrm{dL}$ de cádmio no cordão umbilical. Concluiu que a placenta caracteriza-se como uma melhor barreira para o cádmio que para o chumbo.

Lagerkvist et. al. (1996b), pesquisando os niveis de chumbo no sangue e na placenta de parturientes empregadas em indústrias metalúrgicas manipuladoras de chumbo, verificaram maiores niveis deste metal pesado nesta população, do que em parturientes não trabalhadoras residentes na mesma área; sendo que, os niveis de chumbo no cordāo umbilical foram equivalentes a $85-90 \%$ dos níveis das parturientes.

Hernandez-Avila et. al. (1997) estudaram 1849 parturientes participantes do programa de vigilância de contaminação por chumbo na cidade de México. Os níveis médios de chumbo nos sangues materno e do cordão umbilical foram de $11,2 \mu \mathrm{g} / \mathrm{dL}$ e $10,8 \mu \mathrm{g} / \mathrm{dL}$ respectivamente. A correlação entre ambos foi de $r=0,74$. Oitenta e cinco por cento $(85 \%)$ das parturientes apresentaram niveis de chumbo no sangue superiores a $10 \mu \mathrm{g} / \mathrm{dL}$, e $9,5 \%$ acima de $20 \mu \mathrm{g} / \mathrm{dL}$.

Frenz et. al. (1997) compararam o nivel de chumbo sangüineo em duas populaçōes das cidades de Santiago do Chile e São Felipe, sendo que na primeira cidade a população estava exposta à altos niveis de contaminação atmosférica e na segunda cidade, de acordo com esses autores não havia contaminação. A população foi constituida por 804 recém-nascidos da regiāo urbana (Santiago do Chile) e 165 recém-nascidos da região rural (São Felipe), os quais foram seguidos até completar 2 anos de idade. No início da pesquisa encontrou-se valores médios de $2,99 \mu \mathrm{g} / \mathrm{dL}$ em Santiago do Chile e $1,99 \mu \mathrm{g} / \mathrm{dL}$ em São Felipe, porém no final da pesquisa, observaram-se valores médios de $5,04 \mu \mathrm{g} / \mathrm{dL}$ em Santiago do Chile e 3,65 $\mu \mathrm{g} / \mathrm{dL}$ em São Felipe. Cabe salientar que $6,4 \%$ das crianças de Santiago do Chile aos 2 anos de idade ultrapassaram os $10 \mu \mathrm{g} / \mathrm{dL}$.

Amitai et. al. (1999) compararam os niveis sangüíneos de chumbo entre 156 parturientes e seus respectivos recém-nascidos, residentes a menos de $3 \mathrm{~km}$ de uma indústria metalúrgica com o grupo controle constituido por 175 parturientes e seus 
recém-nascidos na cidade de Kazakhstan, residentes entre 3 a $10 \mathrm{~km}$ de distância do foco de contaminação. Verificou-se que os niveis sangüíneos de chumbo nos casos foram superiores aos controles, tanto nas parturientes como nos recém-nascidos. Observando-se uma forte correlação entre os niveis sangüineos de chumbo das parturientes e seus recém-nascidos para ambos os grupos $(r=0,83$ para os casos e $r=$ 0,56 para os controles). Os recém-nascidos foram acompanhados até completar os 6 meses de idade, Concluindo-se que a exposição intra-uterina ao chumbo está associada com alterações nos sistemas neurocognitivo nestas crianças.

Campagna et. al. (1999) estudaram 241 parturientes na França expostas à contaminação por chumbo e seus respectivos recém-nascidos, através do nível de chumbo e atividade da enzima $\delta-A L A-D$, encontrando as médias geométricas de $6,4 \mu \mathrm{g} / \mathrm{dL}$ e $4,6 \mu \mathrm{g} / \mathrm{dL}$ nos sangues materno e do cordão umbilical, respectivamente, sendo a correlação entre ambas de $r=0,64$.

Gulson et. al. (1999) compararam a relação de chumbo no sangue de 15 parturientes imigrantes de paises do leste da Europa para a Austrália e no sangue dos respectivos recém-nascidos. Estes foram avaliados pelas amostras de sangue venoso aos 60,120 e 180 dias de vida e amostras de urina aos 10,30,60, 90, 120, 150 e 180 dias de vida, tendo como controle recém-nascidos filhos de mães australianas. Observou-se que os niveis de chumbo foram significativamente superiores nas parturientes emigrantes da Austrália e seus respectivos recém-nascidos, que no grupo controle. Concluiram que aexposição à contaminação por chumbo durante a gravidez representa risco principalmente para o recém-nascido, pois este pode ser atingido tanto pela transferência de chumbo através da placenta, como pela mobilização do chumbo durante a lactação.

Krachler et. al. (1999) investigaram a transferência de elementos traço da parturiente para o recém-nascido, além disso, foi analisada a presença do chumbo. Foram analisados o chumbo nos sangues materno e do cordão umbilical de parturientes da Eslovênia, observando-se niveis de chumbo de $0,8 \mu \mathrm{g} / \mathrm{L}$ no sangue materno, $0,4 \mu \mathrm{g} / \mathrm{L}$ no sangue do recém-nascido e $2,6 \mu \mathrm{g} / \mathrm{L}$ no colostro, mostrando que a 
média do nivel de chumbo na parturiente é mais elevado que no recém-nascido, ainda que o nivel deste metal no colostro encontre-se quatro vezes mais elevado que no sangue materno, o que pode ocasionar efeitos adversos no recém-nascido.

Campagna et. al. (2000) examinaram a relação entre os niveis de chumbo no sangue, cabelo e atividade de bomba de cálcio nas células vermelhas em 247 parturientes francesas expostas à contaminação por chumbo e seus respectivos recém-nascidos, encontrando $6,3 \mu \mathrm{g} / \mathrm{dL}$ e $4,8 \mu \mathrm{g} / \mathrm{dL}$ nos sangues materno e do recémnascido; $1,7 \mu \mathrm{g} / \mathrm{g}$ e $1,1 \mu \mathrm{g} / \mathrm{g}$ nos cabelos da mãe e do recém-nascido. Assim mesmo obteve-se uma média de $2442 \mathrm{nM} / \mathrm{mg} / \mathrm{hr}$ (nM de fosfato inorgânico produzido por $\mathrm{mg}$ de proteina por hora) e $2675 \mathrm{nM} / \mathrm{mg} / \mathrm{hr}$ nas células vermelhas da parturiente e do recém nascido, respectivamente. Os efeitos da inibição da enzima $\delta$-ALA-D podem acarretar alterações neurotóxicas, especialmente no recém-nascido.

Navarrete et. al. (2000) avaliaram a relação entre os niveis de chumbo no sangue materno e do cordão umbilical em 1404 pares de parturientes e recémnascidos em 4 hospitais do "Instituto Mexicano del Seguro Social", México, encontrando uma correlação significativa entre os niveis de sangue materno e do cordão umbilical $(r=0,65 ; p<0,01)$.

Um estudo realizado sobre o nivel de chumbo em 132 parturientes indianas de 20 a 25 anos de idade durante o periodo de 1993 a 1997, encontrou correlação positiva entre os niveis de chumbo no sangue materno e no cordão umbilical $(r=0,79)$, atribuindo este resultado à facilidade com que o chumbo atravessa a barreira placentária, representando um sério problema para o feto (Raghunath et. al., 2000).

Audrey et. al. (2002) compararam 160 parturientes de Montreal com 206 parturientes de Paris, tendo como média geométrica dos niveis de chumbo nos sangues materno $2,1 \mu \mathrm{g} / \mathrm{dL}$ e $5,4 \mu \mathrm{g} / \mathrm{dL}$ e do cordão umbilical $1,7 \mu \mathrm{g} / \mathrm{dL}$ e $3,2 \mu \mathrm{g} / \mathrm{dL}$, em ambas parturientes. Cabe destacar que as parturientes moradoras em Paris estavam expostas à contaminação por chumbo, devido à adição desse metal na gasolina. 
Estes resultados sugerem que este metal pesado atravessa livremente a barreira placentária transportando-se da gestante para o feto, corroborando com outros estudos que sugerem que a placenta não é uma barreira natural para o chumbo, colocando o feto em risco de exposição à este metal (Ong et. al., 1985; Sikorski et. al., 1988; Baranowska, 1995; Lagerkvist et. al., 1996a; Raghunath et. al., 2000).

Com o acréscimo de 25 - $80 \%$ do volume sangüineo na gestação, o que se espera é uma maior diluição sangüinea do chumbo com sua queda na concentração. No entanto, o chumbo acumulado nos ossos pode se mobilizar para o sangue durante a gestação e lactação. Portanto, o chumbo estocado nos ossos matemos, quando mobilizado para a circulação sangüínea pode contribuir para a exposição do feto. Estes autores citaram também a ocorrência dessa mobilização na menopausa e em casos de osteoporose (Buchet et. al, 1977; Keller et. al., 1980, Raghunath et. al., 2000).

\subsection{Relação do metabolismo do chumbo com alguns micronutrientes}

Os adultos absorvem, em geral, $10 \%$ do chumbo proveniente da alimentação, elevando-se esta proporção em condições de jejum. Porém, os lactentes e crianças absorvem $50 \%$ de chumbo da alimentação. As dietas pobres em cálcio, fosfato, selênio, zinco, ferro, vitamina $C$ e vitamina $D$ favorecem uma maior absorção de chumbo. Considerando-se que as deficiências dos citados micronutrientes é mais prevalente nas crianças que nos adultos, deduz-se que também por este motivo, elas estão mais expostas a retenção de chumbo nos depósitos corporais (Silbergeld, 1991).

A baixa ingestão de cálcio através da dieta, também pode ocasionar uma desmineralização do osso, o que contribuiria para aumento dos níveis de chumbo, particularmente durante periodos de intensa atividade metabólica do osso, como na gestação (Ong et. al., 1985; Mahaffey et. al., 1986). Isto também pode estar associado com o aumento do requerimento de cálcio pelo feto, durante o último trimestre de gestação (Silbergeld, 1991). Outros autores também associaram deficiência de cálcio com o aumento da absorção do chumbo no trato gastrointestinal (Heard e Chamberlain, 1982; Blake e Mann, 1983; Ong et. al., 1985; Mahaffey e Annest, 1986; 
Mata et. al., 1995). Fullmer et. al (1985) sugerem que uma proteína que se liga ao cálcio poderia participar no transporte intestinal de chumbo.

Hernández-Avila et. al. (1997) observaram uma associação inversa entre consumo de leite e niveis sangüineos de chumbo. O aumento do consumo de leite foi associado com uma significativa diminuição dos niveis de chumbo nos sangues materno e do cordão umbilical $(p<0,001)$. Parturientes que consumiam mais do que 7 copos de leite por semana, tiveram niveis de chumbo mais baixos do que parturientes que consumiam menos do que 7 copos por semana (em média, $-2,3 \mu \mathrm{g} / \mathrm{dL}$ ). Segundo estes mesmos autores, uma adequada ingestão de cálcio, poderia diminuir a absorção gastrointestinal do chumbo.

Outra questão importante é o fato de alguns estudos encontrarem uma relação inversa entre o peso ao nascer e niveis de exposição fetal ao chumbo, estimado pelas concentrações deste metal no sangue do cordão umbilical. Esta importância se deve ao fato do peso ao nascer ser um preditor do crescimento, desenvolvimento e sobrevida de crianças (González-Cossio et. al., 1997).

Em estudo realizado na Califórnia (EUA) por Satin et. al. (1991), observou-se uma associação entre prematuridade e niveis de chumbo no sangue de cordão umbilical. Para niveis de chumbo (cordão umbilical) que excederam $5 \mu \mathrm{g} / \mathrm{dL}$ (média), houve um risco relativo de 2,9 (IC de 95\%: 0,9 - 9,2) para prematuridade. Entretanto, não foi observada associação entre baixo peso $(<2,500 \mathrm{~g})$ e niveis de chumbo no sangue do cordão umbilical.

Tendo em vista os resultados a que chegaram estes pesquisadores, pode-se dizer que o assunto é extremamente importante, principalmente quando nos deparamos com estudos mostrando evidências do acúmulo de chumbo no organismo da gestante e a transferência placentária deste metal pesado para o feto, podendo causar alterações em seu crescimento e desenvolvimento. 


\subsection{Justificativa do local de estudo}

Em Santo Amaro da Purificação-Bahia, Brasil, a contaminação por chumbo, foi inicialmente estudada por um grupo multidisciplinar de professores da Universidade Federal da Bahia. Essas pesquisas revelaram valores de chumbo e cádmio acima dos limites estabelecidos pela regulamentação do meio ambiente (CETESB, 1987), vigente em manguezais e pescadores do estuário do rio Subaé, vegetais produzidos nos arredores da cidade, animais que pastavam em áreas de deposição de escória proveniente de industria metalúrgica manipuladora de chumbo, solo no entomo da industria e crianças com idade até 10 anos residentes em um raio de $900 \mathrm{~m}$ da chaminé da industria (Tavares, 1990).

O primeiro grande dano ambiental nesta cidade veio com o ciclo da cana-deaçúcar, que iniciada em 1655, perdurou como principal agente fomentador da economia da regiāo do Recôncavo até o século XIX (Paim, 1994). A intensidade da devastação das matas para o plantio da cana-de-açúcar era tão grande a ponto de ser criada uma legislação portuguesa para contenção das queimadas no Brasil (Tavares, 1990).

Após o ciclo da cana-de-açúcar veio o ciclo do petróleo. Na década de 30 , com a sua descoberta no Recôncavo Baiano, o processo de industrialização aumentou notadamente e a contaminação ambiental também (Paim, 1994), principalmente nas proximidades da refinaria Landulfo Alves (Tavares, 1990).

Entre os sitios com alto grau de comprometimento ambiental, acha-se o estuário do rio Subaé, tendo como principal fonte de poluição a Companhia Brasileira de Chumbo (COBRAC), empresa de capital francês e nacional, originalmente pertencente ao grupo multinacional Penarroya, que começou a operar em Santo Amaro da Purificação, BA, no ano de 1960, como usina para produzir lingotes de chumbo. Em 1989, a Cobrac foi incorporada à empresa Plumbum Mineração e Metalurgia Ltda, pertencente ao grupo Trevo (Anjos, 1998). 
A indústria metalúrgica, desde o inicio do seu funcionamento, motivou uma série de reclamações por parte da população rural do município. A insatisfação decorria dos primeiros sinais de contaminação, evidenciada pela morte de gado bovino e eqüinos nas áreas adjacentes ao empreendimento (Anjos, 1998).

Essa indústria, desativada em 1993, produziu e depositou aleatoriamente 490,000t de escória contaminada com metais pesados, sobretudo chumbo ( $\mathrm{Pb}$ ) e cádmio (Cd). A escória foi utilizada pela população de Santo Amaro para pavimentar jardins, pátios de casas, praças e áreas escolares, e usada pela Prefeitura para pavimentação de ruas e aterros, contaminando o solo, o rio Subaé e seu estuário, os pescadores e certamente uma parcela significativa da população. Esse material analisado pela Ecolabor Comercial Consultoria e Análises Ltda, localizado em São Paulo, classificou os resíduos em questão como Classe 1 (resíduo perigoso), decorrente da presença de chumbo acima dos limites máximos permitidos para os ensaios da amostra bruta e lixiviação, segundo NBR 10004 (Paim, 1994).

Os estudos desenvolvidos na Bacia do rio Subaé identificaram que as contaminações são decorrentes de: 1-instalação da indústria metalúrgica, em área onde predominam ventos de baixa velocidade e constantes inversōes térmicas, dificultando a dispersão e favorecendo a precipitação de material particulado na área urbana, 2-proximidade desta indústria ao leito e áreas de inundação do rio Subaé, 3transbordamento da bacia de rejeito em períodos de altos indices pluviométricos, 4baixa vazão do rio Subaé, dificultando a diluição e dispersão dos efluentes líquidos lançados sem tratamento, 5-deposição inadequada da escória em aterros, e sua posterior utilização para construção de estradas e áreas residenciais, 6-alta concentração dos metais nos manguezais do estuário do rio Subaé, 7-particulados expelidos pela chaminé da indústria metalúrgica (Anjos, 1998).

Dada a importância dos dados apresentados nessa região do Brasil e a relevância do assunto para a Saúde Pública, decidiu-se desenvolver um estudo avaliando os niveis sangüineos de chumbo, uma vez que pesquisas têm sugerido que baixos niveis de exposicão fetal ao chumbo. estimado pelos níveis de chumbo 
encontrado no sangue de cordão umbilical, pode ter um efeito adverso no recémnascido. 


\section{Objetivos}

- Comparar as médias dos niveis de chumbo das parturientes, segundo a distância entre o local de residência e a fonte de contaminação de chumbo.

-Determinar a relação entre os niveis de chumbo de parturientes e seus respectivos recém-nascidos, analisadas através de dois métodos.

-Verificar os fatores preditores dos elevados niveis de chumbo nas parturientes.

-Verificar os fatores preditores dos elevados niveis de chumbo nos recém-nascidos. 


\section{Materiais e Métodos}

\subsection{Delineamento}

Este é um estudo transversal observacional, no qual foi analisado simultaneamente o par parturiente/recém-nascido.

\subsection{Local}

O estudo foi realizado no "Hospital Matemidade de Santo Amaro", localizado no município de Santo Amaro da Purificação-Bahia, que é apontado como uma região brasileira de elevada prevalência de contaminação por chumbo (Carvalho et. al., 1983; Carvalho et. al., 1987; Tavares, 1990).

O município de Santo Amaro surgiu por volta de 1557 quando os primeiros civilizadores chegaram. Em 5 de janeiro de 1727, Santo Amaro foi elevada a categoria de vila e após a lei Provincial $n^{\circ} 43$ de 13 de março de 1837 foi elevada a categoria de cidade (Paim, 1994).

O municipio de Santo Amaro da Purificação está localizado na região central do Recôncavo do Estado da Bahia às margens do rio Subaé perto da confluência do rio Traripe e do mar, a cerca de $75 \mathrm{~km}$ da capital baiana. $O$ acesso ao municipio a partir de Salvador é totalmente asfaltado e envolve trechos das rodovias BR 324 e BA 096. Localiza-se próximo as cidades de Conceição de Jacuipe e Amélia Rodrigues ao norte, Saubara ao sul, São Sebastião do Passé e São Francisco do Conde ao leste e São Gonçalo dos Campos, Feira de Santana e Cachoeira a oeste (Paim, 1994) (Figura 1).

A área total do município de Santo Amaro é de $486,2 \mathrm{~km}^{2}$ e sua população é de 58,394 habitantes, sendo 44,490 residentes na área urbana (IBGE, 2000). A produção econômica basea-se no cultivo de pau-brasil, cana-de-açúcar, pesca de baleia, farinha de mandioca, industrial têxtil, petrolifero, industrial extrativo, industria de transformação, petroquímica e turismo. 


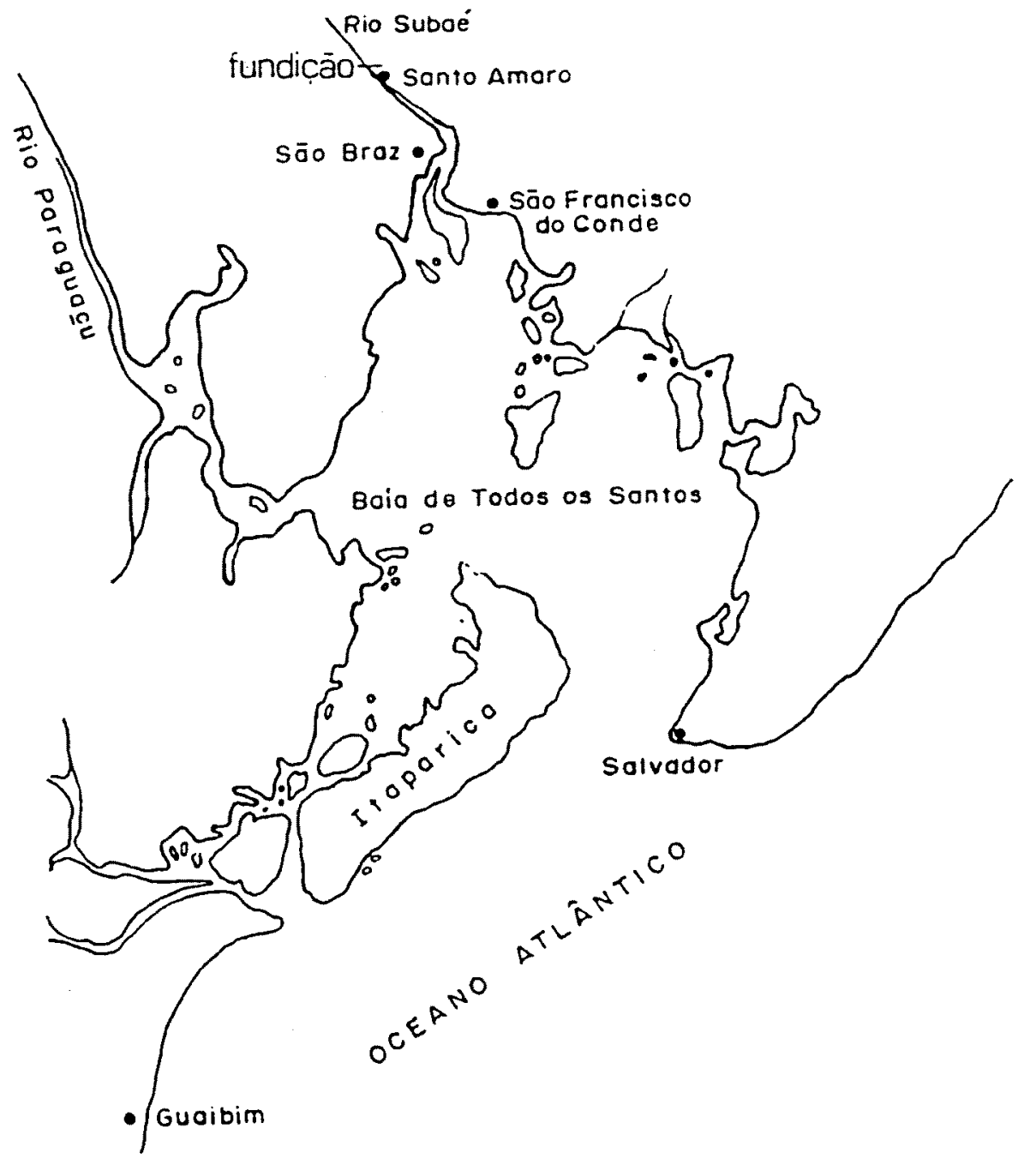

Fig. 1. Mapa esquemático mostrando a localização da fun diçāo 


\subsection{População}

-Critérios de inclusão: Foram selecionadas todas as parturientes admitidas no "Hospital Maternidade de Santo Amaro", para realização do parto, no periodo de junho a agosto de 2002.

-Critérios de exclusão: Pares de parturiente/recém-nascido que não eram moradoras da área delimitada para este estudo ( $5 \mathrm{~km}$ ao redor da indústria metalürgica), parturientes portadoras de doenças agudas, crônicas e metabólicas e gemelaridade.

\subsubsection{Amostragem}

Segundo diversos estudos, as correlaçōes entre os niveis de chumbo no sangue materno $(x)$ e no cordão umbilical $(y)$ foram de $r=0,63$ (Ong et. al., 1985), $r=0,65$ (Navarrete et. al., 2000), $r=0,68$ (Schuhmacher et. al., 1996), $r=0,74$ (Hemandez-Avila et. al., 1997), $r=0,77$ (Korpela et. al., 1986), $r=0,79$ (Raghunath et. al., 2000). Para o cálculo da amostra, optou-se pela escolha de uma correlação menor $(r=0,50)$, pois este número permitiria considerar como significativos os coeficientes de correlação iguais ou acima de 0,50 .

Supondo $\alpha=5 \%, \beta=10 \%$ e uma perda de $20 \%$, estimou-se que seriam necessárias 50 parturientes (Hulley e Cummings, 1988).

\subsection{Coleta de dados antropométricos e demográficos}

Após a admissão para realização do parto, as parturientes foram esclarecidas a respeito da pesquisa, sendo solicitado o consentimento formal para iniciar a coleta de dados e das amostras de sangue. 


\subsubsection{Parturientes}

As parturientes foram pesadas e medidas antes do parto. No caso do peso, utilizou-se balança portátil, solar, da marca Seca, modelo 7500, com capacidade para $150 \mathrm{~kg}$ e precisão de $100 \mathrm{~g}$. No caso da altura, utilizou-se o antropômetro fixo em parede, da marca Stanley, com precisão de $0,1 \mathrm{~cm}$.

Em momento oportuno antes ou depois do parto, as parturientes responderam a um questionário elaborado especificamente para este estudo (Anexo 1), a fim de se obter informações relativas à variáveis sócio-econômicas, demográficas, obstétricas, e dados sobre o recém-nascido. Informações não referidas com certeza pelas entrevistadas foram confirmadas mediante consulta ao prontuário médico.

Também foi aplicado um Questionário de Freqüência Alimentar (QFA) para verificar o consumo de cálcio, consumo de ferro e consumo de vitamina $C$ (Anexo 2). $O$ QFA foi constituido por uma lista de alimentos de maior consumo pela população em estudo, obtida através de três recordatórios de $24 \mathrm{~h}$ realizados em 100 mães com um intervalo de 30 dias entre cada um destes. Tais recordatórios foram aplicados por entrevistadores treinados (bolsistas de apoio técnico da FAPESP).

Os dados dos recordatórios foram tabulados e tanto os alimentos como as porções médias expressas em "medidas caseiras" que se repetiram mais de cinco vezes (ponto de coorte adotado para este estudo) entre as 100 mães entrevistadas residentes no centro e na periferia deste municipio, foram incluidos no QFA. As informações sobre a freqüência alimentar foram processadas através do software NutriSurvey for window 95 (Erhardt, 1999). Neste software foram incluidos o banco de dados contendo a composição de alimentos do IBGE (1996). 


\subsubsection{Recém-nascidos}

Os dados antropométricos e demais dados relacionados às condições de nascimento dos recém-nascidos foram coletados no livro de registros do berçário do hospital.

\subsection{Amostras de sangue}

\subsubsection{Colheita}

Antes do parto foram coletados, aproximadamente, $2 \mathrm{ml}$ de sangue venoso das parturientes. No parto foram coletados $2 \mathrm{ml}$ de sangue do cordão umbilical usando heparina como anticoagulante para as análises do chumbo em ambos casos. Estas amostras foram coletadas em duplicata.

Os tubos contendo as amostras de sangue materno e do cordão umbilical foram identificados com etiqueta contendo o número do par parturiente/recém-nascido, nome completo da parturiente, as iniciais maiúsculas " $M$ " (mãe) ou "RN" (recém nascido), e a data da colheita.

\subsubsection{Envio para os locais de análise}

Ao chegarem no Laboratório do Hospital Maternidade de Santo Amaro, as amostras de sangue foram separadas em aliquotas para serem distribuídas aos locais onde seriam realizadas as diferentes dosagens hematológicas. As amostras de sangue tanto para a análise do chumbo através do "LeadCare" como a determinação da hemoglobina através do "HemoCue" foram realizadas no mesmo dia da colheita, sendo que as amostras de sangue para a análise de chumbo através do método de espectrofotometria de absorção atômica com forno de grafite, foram devidamente estocadas em geladeira a $6^{\circ} \mathrm{C}$. Em momento oportuno estas amostras foram enviadas 
para São Paulo onde foram analisadas no Laboratório de Divisão Quimica do Instituto Adolfo Lutz.

\subsection{Análise do chumbo}

\subsubsection{Espectrofotometria de absorção atômica com forno de grafite (AA-FG)}

A determinação do chumbo nas amostras de sangue total foi realizada por AAFG, equipado com corretor de fundo com efeito Zeeman, utilizando como modificador quimico uma mistura de dihidrogenofosfato de amônio e nitrato de magnésio. As amostras de sangue foram diluidas em Triton X-100 e ácido nitrico (Association of Official Analytical Chemists, 1995).

Este método consiste na atomização da amostra em um tubo de grafite aquecido eletrotérmicamente. O tubo de grafite é colocado no compartimento de amostra de um espectrofotômetro de absorção atômica com o feixe de radiação passando através dele. Um pequeno volume de solução é quantitativamente colocado através de um orificio localizado no centro da parede do tubo. O tubo é então aquecido pela passagem da corrente elétrica através de uma seqüência de temperaturas programadas em várias etapas.

A programação térmica deve ser feita de maneira tal que primeiro haja uma temperatura adequada para evaporar o solvente da solução; em seguida a temperatura deve ser aumentada a fim de transformar a amostra em cinzas e, finalmente, em outra etapa, a temperatura deve ser suficiente para dissociar o composto do analito presente na amostra nos átomos que irão absorver a radiação emitida pela fonte.

Quando a atomização começa, átomos do analito são formados aumentando assim o sinal da absorvância. O sinal continuará aumentar até que a taxa de átomos torne-se menor que a difusão dos átomos para fora do tubo. Neste ponto, a queda na população de átomos resulta na diminuição do sinal de absorbância, que decairá a 
zero. O formato de pico resultante das medidas de absorbância é registrado e a altura do pico ou sua área são usados como sinal analítico para quantificação.

\subsubsection{Eletroquímica-"LeadCare"}

As amostras coletadas em tubo com heparina foram analisadas também através do aparelho portátil "LeadCare", Este método funciona à base de eletroquimica e sensores disponiveis que detectam o chumbo em sangue total. A maior parte do chumbo é transportada nas células vermelhas do sangue. Quando se mistura a amostra do sangue com o tratamento reativo, o chumbo nas células vermelhas do sangue é removido, sendo detectado. Quando se inicia o teste, o analisador faz com que o chumbo se concentre no sensor "LeadCare". Depois de um período de tempo, o analisador remove o chumbo, realiza a medida e converte este resultado em um valor numérico de chumbo no sangue que logo em seguida aparecerá na tela do aparelho (ESA e AndCare, s.d.).

\subsection{Determinaçāo de Hemoglobina}

Foi realizado através do hemoglobinômetro portátil "HemoCue®", utilizando-se sangue venoso da parturiente e sangue do cordão umbilical (mistura de sangue venoso e arterial). Este aparelho se baseia no princípio descrito por Vanzeti (1996). O desoxicolato de sódio presente no interior da cubeta, quando em contato com o sangue, hemolisa os eritrócitos liberando a hemoglobina, a qual é convertida em metahemoglobina pelo nitrito de sódio. Em seguida, a metahemoglobina reage com a azida de sódio, resultando em azida-metahemoglobina. A absorbância é medida em dois comprimentos de onda (570 a $880 \mathrm{~mm}$ ), a fim de compensar a turvação da amostra (Vanzeti, 1996; ASEM-NPBI, s.d.). 


\subsection{Variáveis em estudo}

3.8.1.Variáveis para caracterização das parturientes:

-Idade

-Estado civil

-Escolaridade

-Ocupação

-Renda familiar e renda per capita),

-Tipo de parto

-Número de gestações anteriores

-Número de filhos vivos

-Número de abortos

-Uso de suplementos

-Peso

-Altura

-índice de massa corporal (peso/altura²).

3.8.2.Variáveis para caracterização do recém-nascido:

-Sexo

-Comprimento

- Peso ao nascer

\subsubsection{Variáveis de interesse:}

-Niveis de chumbo nos sangues das parturientes e do cordão umbilical

-Niveis hemoglobina nos sangues das parturientes e do cordão umbilical -Distância entre o local de moradia e a fonte contaminadora de chumbo -Consumo de cálcio

-Consumo de ferro e

-Consumo de vitamina $\mathrm{C}$ 


\subsection{Análise estatística}

A construção do banco de dados e a análise estatistica foram realizados com o auxilio do pacote estatístico "Statistical Package for the Social Science" (SPSS), versão 10.0.

Primeiramente foi feita a análise descritiva da amostra por médio de média, desvio padrão, valores mínimos, valores máximos e proporções.

Todas as variáveis bioquímicas tiveram distribuição normal, avaliado pelo teste de Kolmogorov-Smirnov.

Para avaliar as diferenças entre as médias dos niveis de chumbo das parturientes em relação à fonte de contaminação de chumbo foi utilizado o teste "t de Student", sendo que a homogeneidade das variâncias foi avaliado pelo teste de Levene.

A relação entre os niveis de chumbo das parturientes e os recém-nascidos foi analisada através do coeficiente de correlação de Pearson.

Por último foram estimados modelos de regressão linear múltipla, separadamente para a parturiente e para o recém-nascido, tendo como variável dependente o chumbo medido por AA-FG. Inicialmente estimou-se os coeficientes de correlação de Pearson entre a variável dependente e as variáveis independentes. As variáveis independentes para a parturiente foram peso, idade, estatura, índice de massa corporal, número de gestações, filhos vivos, renda per capita, hemoglobina, consumo de cálcio, consumo de ferro e consumo de vitamina $\mathrm{C}$. As variáveis independentes para o recém-nascido foram comprimento, peso, sexo, renda per capita e hemoglobina.

O processo de modelagem foi o "stepwise forward selection", onde a partir do modelo com a variável independente com maior valor de coeficiente de correlação de Pearson ( $r$ ), acrescentou-se as outras, uma a uma. Foi feita análise dos residuos do modelo final, que mostraram-se homogêneos e sem viéses. 
Em todas as análises utilizou-se o nivel de significância de $5 \%$.

\subsection{Aspectos éticos}

O desenvolvimento do estudo seguiu os requisitos da Resolução 196/96 do Conselho Nacional de Saúde/Ministério da Saúde do Brasil (MINISTÉRIO DA SAÚDE 2003), e as Normas Internas da Faculdade de Saúde Pública - USP, que regulamentam pesquisas envolvendo seres humanos. Cada parturiente envolvida no estudo recebeu informações a respeito do trabalho, os objetivos e metodologia, e foram informadas do direito de recusa à participação em qualquer momento da pesquisa, sem prejuizo ou penalidade de qualquer natureza, sendo resguardada a integridade das parturientes, e garantida a privacidade dos dados e informaçōes obtidos no estudo.

Após os esclarecimentos, o pesquisador e a parturiente assinaram um termo de consentimento, elaborado em duas vias, uma para cada assinante (Anexo 3).

O presente estudo foi aprovado pela Comissão de Ética em Pesquisa da Faculdade de Saúde Pública e pela Comissão de Ética do Hospital Maternidade de Santo Amaro onde foi realizado o estudo. (anexo 4).

Os resultados deste estudo foram encaminhados para a Secretária de Saúde de Santo Amaro da Purificação na Bahia. 


\section{Resultados}

\subsection{Características das parturientes}

\subsubsection{Caracteristicas demográficas e sócio-econômicas}

Conforme mostra a Tabela $1,74,5 \%$ das parturientes tinham entre 20 e 33 anos de idade. $A$ idade média das parturientes foi de 23 anos (desvio padrão $=4,6$ anos).

Observou-se que a maior parte das parturientes eram solteiras morando com companheiro $(78,2 \%), 41,8 \%$ das parturientes tinham cursado até $3^{a}$ série do ensino fundamental (< 4 anos de educação) e $94,5 \%$ eram donas de casa.

A renda familiar de $67,3 \%$ das parturientes era menor ou igual a um (1) salário minimo e a renda per capita de $52,7 \%$ das parturientes se encontrava na faixa até 0,25 salário minimo.

Todas as parturientes envolvidas neste estudo (100\%) tiveram parto financiado pelo Sistema Único de Saúde (SUS). 
Tabela 1. Número e percentual de parturientes, segundo caracteristicas demográficas e sócio-econômicas. Santo Amaro-BA, 2002.

\begin{tabular}{|c|c|c|}
\hline Variáveis & $\mathrm{N}^{0}$ & $\%$ \\
\hline $\begin{array}{l}\text { Faixa etária } \\
14 \text { a } 19 \text { anos } \\
20 \text { a } 33 \text { anos } \\
\geq 34 \text { anos }\end{array}$ & $\begin{array}{l}12 \\
41 \\
02\end{array}$ & $\begin{array}{r}21,9 \\
74,5 \\
3,6\end{array}$ \\
\hline $\begin{array}{l}\text { Estado civil } \\
\text { Solteira sem companheiro } \\
\text { Solteira com companheiro } \\
\text { Casada }\end{array}$ & $\begin{array}{l}05 \\
43 \\
07\end{array}$ & $\begin{array}{r}9,1 \\
78,2 \\
12,7\end{array}$ \\
\hline $\begin{array}{l}\text { Escolaridade } \\
\text { Da } 1^{\mathrm{a}} \text { a } 3^{\mathrm{a}} \text { série do ensino fundamental } \\
\text { Até } 4^{\mathrm{a}} \text { série do ensino fundamental } \\
\text { Da } 5^{\mathrm{a}} \text { a } 7^{\mathrm{a}} \text { série do ensino fundamental } \\
\text { Até } 8^{\mathrm{a}} \text { série do ensino fundamental } \\
\text { Da } 1^{\circ} \text { a } 2^{\circ} \text { ano do ensino médio } \\
\text { Até } 3^{\circ} \text { ano do ensino médio }\end{array}$ & $\begin{array}{l}23 \\
15 \\
11 \\
4 \\
1 \\
1\end{array}$ & $\begin{array}{r}41,8 \\
27,3 \\
20,0 \\
7,3 \\
1,8 \\
1,8\end{array}$ \\
\hline $\begin{array}{l}\text { Ocupação } \\
\text { Dona de casa } \\
\text { Trabalha fora de casa }\end{array}$ & $\begin{array}{l}52 \\
03\end{array}$ & $\begin{array}{r}94,5 \\
5,5\end{array}$ \\
\hline $\begin{array}{l}\text { Renda Familiar mensal } \\
\text { Até } 1 \mathrm{SM}^{*} \\
1,1 \text { a } 2,0 \\
2,1 \text { a } 5,0\end{array}$ & $\begin{array}{l}37 \\
14 \\
04\end{array}$ & $\begin{array}{r}67,3 \\
25,5 \\
7,3\end{array}$ \\
\hline $\begin{array}{l}\text { Renda Per Capita } \\
\text { Até } 0,25 \mathrm{SM} \\
0,26 \text { a } 0,50 \mathrm{SM} \\
0,51 \text { a } 1 \mathrm{SM} \\
\geq 1,01 \mathrm{SM}\end{array}$ & $\begin{array}{l}29 \\
15 \\
08 \\
03 \\
\end{array}$ & $\begin{array}{r}52,7 \\
27,4 \\
14,5 \\
5,4 \\
\end{array}$ \\
\hline Total & 55 & 100,0 \\
\hline
\end{tabular}

- SM= salário mínimo $(\mathrm{R} \$ 200,00)$ 


\subsubsection{Caracteristicas obstétricas}

Verificou-se que a maioria das parturientes teve parto normal $(96,4 \%)$ e que $61,8 \%$ eram multigestas (Tabela 2 ).

Tabela 2. Número e percentual de parturientes segundo o tipo de parto e número de gestações. Santo Amaro-BA, 2002.

\begin{tabular}{|c|c|c|}
\hline Variáveis & № & $\%$ \\
\hline $\begin{array}{l}\text { Tipo de parto } \\
\text { Normal } \\
\text { Cesárea }\end{array}$ & $\begin{array}{l}53 \\
02\end{array}$ & $\begin{array}{r}96,4 \\
3,6\end{array}$ \\
\hline $\begin{array}{l}\text { Número de gestações } \\
\text { Primigesta } \\
\text { Multigesta (2 a } 4 \text { gestações) } \\
\text { Multigesta (5 a + gestações) }\end{array}$ & $\begin{array}{l}21 \\
32 \\
02 \\
\end{array}$ & $\begin{array}{r}38,2 \\
58,2 \\
3,6 \\
\end{array}$ \\
\hline Total & 55 & 100,0 \\
\hline
\end{tabular}

\subsubsection{Uso de suplementos}

Somente $31 \%$ e $9,1 \%$ das parturientes referiam o consumo de ferro (em forma de sulfato ferroso) e cálcio respectivamente.

\subsubsection{Características antropométricas}

Observou-se que $47,3 \%$ das parturientes estão dentro da faixa de normalidade para mulheres adultas não grávidas, que vai de 18,5 a $24,9 \mathrm{~kg} / \mathrm{m}^{2}$ (WHO 1998) (Tabela 3). 
Tabela 3. Número e percentual das parturientes segundo Indice de Massa Corporal (IMC). Santo Amaro-BA, 2002.

\begin{tabular}{l|cc}
\hline \multicolumn{1}{c|}{ IMC $\left(\mathrm{kg} / \mathrm{m}^{2}\right)$} & \multicolumn{2}{|c}{ Parturientes } \\
\hline$<18,5$ & 01 & 1,7 \\
\hline 18,5 a 24,9 & 26 & 47,3 \\
25 a 29,9 & 25 & 45,5 \\
$\geq 30$ & 03 & 5,5 \\
\hline Total & 55 & 100,0 \\
\hline
\end{tabular}

\subsection{Características dos recém-nascidos}

Entre os recém-nascidos, $30(54,5 \%)$ eram do sexo masculino e $25(45,5 \%)$ do sexo feminino.

Neste estudo, 5,5\% dos recém nascidos a termo apresentaram baixo peso ao nascer $(<2,500 \mathrm{~g})$, e $1,8 \%$ tiveram peso ao nascer igual ou maior do que $4,000 \mathrm{~g}$ (Tabela 4).

Tabela 4. Número e percentual dos recém-nascidos, segundo peso ao nascer e sexo. Santo Amaro-BA, 2002.

\begin{tabular}{|c|c|c|c|c|c|c|}
\hline \multirow[t]{2}{*}{ Peso (g) } & \multicolumn{2}{|c|}{ Masculino } & \multicolumn{2}{|c|}{ Feminino } & \multicolumn{2}{|c|}{ Total } \\
\hline & $N^{\circ}$ & $\%$ & Nㅡㅇ & $\%$ & NNo & $\%$ \\
\hline$<2,500$ & 01 & 3,3 & 2 & 8,0 & 03 & 5,5 \\
\hline 2,500 a 4,000 & 29 & 96,7 & 22 & 88,0 & 51 & 92,7 \\
\hline$\geq 4,000$ & - & - & 01 & 4,0 & 01 & 1,8 \\
\hline Total & 30 & 100,0 & 25 & 100,0 & 55 & 100,0 \\
\hline
\end{tabular}




\subsection{Niveis sangüineos de chumbo em parturientes e recém-nascidos (cordão umbilical)}

4.3.1. Niveis de chumbo das parturientes em relação ao foco de contaminação

Na Tabela 5 observa-se que as médias dos niveis sangüineos de chumbo das parturientes que moram perto da fonte de contaminação foram maiores que as médias dos niveis sangüineos de chumbo no sangue das parturientes que moram à distância média ou longe.

Tabela 5. Comparação das médias dos níveis sangüíneos de chumbo de acordo com as distâncias em relação à fonte de contaminação de chumbo. Santo Amaro-BA, 2002.

\begin{tabular}{|c|c|c|c|c|}
\hline Distância & & $\begin{array}{l}\text { tes } \\
\%\end{array}$ & Média & Desvio padrão \\
\hline Perto* & 13 & 23,6 & 9,123 & 5,127 \\
\hline Média** & 33 & 60,0 & 4,794 & 1,605 \\
\hline Longe ${ }^{\star \star *}$ & 09 & 16,4 & 1,111 & 1,330 \\
\hline
\end{tabular}

4.3.2. Relação dos niveis de chumbo das parturientes e seus respectivos recémnascidos

A Tabela 6 apresenta as medidas de tendência central do chumbo estudado no sangue das parturientes e seus respectivos recém-nascidos, determinados através de AA-FG e eletroquimica-"LeadCare". 
Verificou-se que as médias dos niveis de chumbo no sangue das parturientes foram maiores que as médias dos niveis de chumbo no sangue dos recém-nascidos, independente do método utilizado para a determinação de chumbo, (AA-FG, p<0,039; ou eletroquimica-“LeadCare”, $p<0,001$ ).

Tabela 6. Estatistica descritiva dos niveis sangüineos de chumbo (avaliado por Espectrofotometria-AA-FG e eletroquimica- "LeadCare"), segundo parturiente e recémnascido. Santo Amaro-BA, 2002.

\begin{tabular}{|c|c|c|c|c|c|c|c|}
\hline \multirow[t]{2}{*}{ Parâmetros } & \multicolumn{3}{|c|}{$\begin{array}{l}\text { Parturientes } \\
(\mathrm{N}=55)\end{array}$} & \multicolumn{3}{|c|}{$\begin{array}{c}\text { Recém-nascido } \\
(N=55)\end{array}$} & \multirow[b]{2}{*}{$\mathrm{p}^{*}$} \\
\hline & $\begin{array}{l}\text { Média } \\
\text { (DP) }\end{array}$ & Mediana & $\begin{array}{l}\text { Min } \\
\text { Máx }\end{array}$ & $\begin{array}{l}\text { Média } \\
\text { (DP) }\end{array}$ & Mediana & $\begin{array}{l}\text { Min } \\
\text { Máx }\end{array}$ & \\
\hline Chumbo por AA-FG $(\mu \mathrm{g} / \mathrm{dl})$ & $\begin{array}{c}5,215 \\
(3,771)\end{array}$ & 4,700 & $\begin{array}{r}0,0 \\
24,2\end{array}$ & $\begin{array}{c}3,884 \\
(3,583)\end{array}$ & 3,400 & $\begin{array}{r}0,0 \\
17,0\end{array}$ & $<0,039$ \\
\hline $\begin{array}{l}\text { Chumbo por Eletroquímica- } \\
\text { "LeadCare" ( } \mu \mathrm{g} / \mathrm{dl})\end{array}$ & $\begin{array}{c}5,720 \\
(1,829)\end{array}$ & 5,700 & $\begin{array}{r}2,6 \\
10,2\end{array}$ & $\begin{array}{c}3,145 \\
(1,104)\end{array}$ & 3,100 & $\begin{array}{l}1,0 \\
6,3 \\
\end{array}$ & $<0,001$ \\
\hline
\end{tabular}

$\mathrm{p}^{*}$ : Teste t-Student

Houve boa correlação entre o chumbo encontrado nas parturientes e recémnascidos tanto através do método da AA-FG como do método de eletroquímica"LeadCare" (Tabela 7).

Tabela 7. Coeficiente de correlação entre os parâmetros analisados nas parturientes e nos recém-nascidos. Santo Amaro-BA, 2002.

\begin{tabular}{c|cc}
\hline Parâmetros & $r$ & $(p)$ \\
\hline Chumbo Espectrofotometria & 0,86 & $(<0,001)$ \\
Chumbo eletroquimica-“LeadCare" & 0,73 & $(<0,001)$ \\
\hline
\end{tabular}




\subsubsection{Modelos de regressão da parturiente}

Os coeficientes de correlação de Pearson ( $r$ ) entre o nivel sangüíneo de chumbo das parturientes $e$ as variáveis independentes são indicados na Tabela 8. Observou-se que apenas o peso teve correlação significativa com a variável dependente.

Tabela 8. Coeficientes de correlação de Pearson entre o nível sangüineo de chumbo das parturientes e variáveis em estudo. Santo Amaro-BA, 2002.

\begin{tabular}{l|c}
\hline \multicolumn{1}{c|}{ Variáveis } & $r(p)$ \\
\hline Peso & $-0,27(0,046)$ \\
Idade & $0,03(0,816)$ \\
Estatura & $-0,11(0,395)$ \\
Indice de Massa Corporal & $-0,23(0,089)$ \\
Número de gestações & $0,09(0,502)$ \\
Filhos vivos & $0,13(0,324)$ \\
Renda per capita & $0,01(0,939)$ \\
Hemoglobina & $-0,18(0,173)$ \\
Consumo de cálcio & $-0,23(0,095)$ \\
Consumo de ferro & $-0,03(0,829)$ \\
Consumo de vitamina C & $0,11(0,440)$ \\
\hline
\end{tabular}

A Tabela 9 apresenta os detalhes da modelagem estatistica do nivel sangüíneo de chumbo das parturientes. Iniciou-se o processo de modelagem com o peso, e na presença desta variável, as variáveis idade, estatura, Índice de Massa Corporal, número de gestações, filhos vivos, renda per capita, consumo de ferro e consumo de vitamina $\mathrm{C}$ não foram significativas.

O melhor modelo de predição envolveu o peso, a hemoglobina e o consumo de cálcio (modelo 12). Conclue-se, portanto, que foram fatores independentes 
correlacionados com os niveis de chumbo das parturientes o peso $(B=-0,420 ; p=0,003)$, a hemoglobina $(B=-0,269 ; p=0,049)$ e o consumo de cálcio $(B=-0,258 ; p=0,050)$. Foi feita a análise de residuos e constatou-se que o modelo final não apresentava viés (anexo 5).

Tabela 9. Modelos de regressão para os niveis sangüineos de chumbo das parturientes. Santo Amaro-BA, 2002.

\begin{tabular}{|c|c|c|c|c|}
\hline Modelos & Variáveis independentes & B & $\mathrm{P}$ & $\begin{array}{c}r^{2} \\
\text { ajustado }\end{array}$ \\
\hline 1 & Peso & $-0,103$ & 0,046 & 0,055 \\
\hline 2 & $\begin{array}{l}\text { Peso } \\
\text { Idade }\end{array}$ & $\begin{array}{l}-0,104 \\
+0,041\end{array}$ & $\begin{array}{l}0,046 \\
0,706\end{array}$ & 0,040 \\
\hline 3 & $\begin{array}{l}\text { Peso } \\
\text { Estatura }\end{array}$ & $\begin{array}{l}-0,271 \\
0,003\end{array}$ & $\begin{array}{l}0,074 \\
0,982\end{array}$ & 0,073 \\
\hline 4 & $\begin{array}{c}\text { Peso } \\
\text { İndice de Massa Corporal }\end{array}$ & $\begin{array}{l}-0,271 \\
0,002\end{array}$ & $\begin{array}{l}0,302 \\
0,995\end{array}$ & 0,073 \\
\hline 5 & $\begin{array}{l}\text { Peso } \\
\text { Número de gestaçōes }\end{array}$ & $\begin{array}{c}-0,269 \\
0,089\end{array}$ & $\begin{array}{l}0,048 \\
0,506\end{array}$ & 0,081 \\
\hline 6 & $\begin{array}{l}\text { Peso } \\
\text { Filhos vivos }\end{array}$ & $\begin{array}{l}-0,276 \\
0,146\end{array}$ & $\begin{array}{l}0,042 \\
0,273\end{array}$ & 0,094 \\
\hline 7 & $\begin{array}{l}\text { Peso } \\
\text { Renda per capita }\end{array}$ & $\begin{array}{r}-0,271 \\
0,022\end{array}$ & $\begin{array}{l}0,048 \\
0,868\end{array}$ & 0,073 \\
\hline 8 & $\begin{array}{c}\text { Peso } \\
\text { Hemoglobina }\end{array}$ & $\begin{array}{l}-0,144 \\
-0,935\end{array}$ & $\begin{array}{l}0,007 \\
0,023\end{array}$ & 0,129 \\
\hline 9 & $\begin{array}{c}\text { Peso } \\
\text { Consumo de cálcio }\end{array}$ & $\begin{array}{r}-0,129 \\
-0,008\end{array}$ & $\begin{array}{l}0,012 \\
0,024\end{array}$ & 0,128 \\
\hline 10 & $\begin{array}{c}\text { Peso } \\
\text { Consumo de ferro }\end{array}$ & $\begin{array}{l}-0,106 \\
+0,027\end{array}$ & $\begin{array}{l}0,047 \\
0,780\end{array}$ & 0,039 \\
\hline 11 & $\begin{array}{c}\text { Peso } \\
\text { Consumo de vit } \mathrm{C}\end{array}$ & $\begin{array}{l}-0,111 \\
+0,006\end{array}$ & $\begin{array}{l}0,033 \\
0,270\end{array}$ & 0,060 \\
\hline 12 & $\begin{array}{c}\text { Peso } \\
\text { Hemoglobina } \\
\text { Consumo de cálcio }\end{array}$ & $\begin{array}{l}-0,420 \\
-0,269 \\
-0,258\end{array}$ & $\begin{array}{l}0,003 \\
0,049 \\
0,050\end{array}$ & 0,222 \\
\hline
\end{tabular}




\subsubsection{Modelos de regressão do recém-nascido}

Os coeficientes de correlação de Pearson ( $r$ ) entre o nivel sangüineo de chumbo dos recém-nascidos e as variáveis independentes são indicados na Tabela 10. Observou-se que apenas o comprimento teve correlação significativa com a variável dependente.

Tabela 10. Coeficientes de correlação de Pearson entre o nivel sangüineo de chumbo dos recém-nascidos e variáveis em estudo. Santo Amaro-BA, 2002.

\begin{tabular}{l|c}
\hline \multicolumn{1}{c|}{ Variáveis } & $r(p)$ \\
\hline Comprimento & $-0,32(0,017)$ \\
Peso & $-0,04(0,763)$ \\
Sexo & $0,10(0,455)$ \\
Renda per capita & $0,09(0,513)$ \\
Hemoglobina & $-0,04(0,721)$ \\
\hline
\end{tabular}

A Tabela 11 apresenta os detalhes da modelagem estatistica do nivel sangüineo de chumbo dos recém-nascidos. Iniciou-se o modelo com o comprimento e o peso, sendo ambos significativos.

Na presença do peso, quando o sexo, renda per capita e hemoglobina foram introduzidos um a um no modelo, eles não foram significativos.

O melhor modelo de prediçăo envolveu o comprimento e o peso (modelo 2). Conclue-se, portanto, que foram fatores independentes correlacionados com os niveis de chumbo do recém nascido, o comprimento $(B=-0,460 ; p=0,003)$ e o peso $(B=-0,275$; $p=0,048$ ). Foi feita a análise de residuos e constatou-se que o modelo final não apresentava viés (Anexo 5). 
Tabela 11. Modelos de regressão para os níveis sangüíneos de chumbo dos recémnascidos. Santo Amaro-BA, 2002.

\begin{tabular}{|c|c|c|c|c|}
\hline Modelos & $\begin{array}{c}\text { Variáveis } \\
\text { independentes }\end{array}$ & B & $P$ & $\frac{r^{2}}{\text { ajustado }}$ \\
\hline 1 & Comprimento & $-0,321$ & 0,017 & 0,103 \\
\hline 2 & $\begin{array}{c}\text { Comprimento } \\
\text { Peso }\end{array}$ & $\begin{array}{l}-0,460 \\
-0,275\end{array}$ & $\begin{array}{l}0,003 \\
0,048\end{array}$ & 0,159 \\
\hline 3 & $\begin{array}{l}\text { Comprimento } \\
\text { Sexo }\end{array}$ & $\begin{array}{l}-0,571 \\
+0,624\end{array}$ & $\begin{array}{l}0,019 \\
0,507\end{array}$ & 0,076 \\
\hline 4 & $\begin{array}{l}\text { Comprimento } \\
\text { Renda per } \\
\text { capita }\end{array}$ & $\begin{array}{c}-0,326 \\
0,107\end{array}$ & $\begin{array}{l}0,016 \\
0,417\end{array}$ & 0,114 \\
\hline 5 & $\begin{array}{l}\text { Comprimento } \\
\text { Hemoglobina }\end{array}$ & $\begin{array}{l}-0,605 \\
-0,260\end{array}$ & $\begin{array}{l}0,014 \\
0,460\end{array}$ & 0,078 \\
\hline 6 & $\begin{array}{c}\text { Comprimento } \\
\text { Peso } \\
\text { Sexo }\end{array}$ & $\begin{array}{c}-0,467 \\
-0,301 \\
0,132\end{array}$ & $\begin{array}{l}0,003 \\
0,050 \\
0,313\end{array}$ & 0,176 \\
\hline 7 & $\begin{array}{l}\text { Comprimento } \\
\text { Peso } \\
\text { Hemoglobina }\end{array}$ & $\begin{array}{l}-0,463 \\
-0,263 \\
-0,059\end{array}$ & $\begin{array}{l}0,003 \\
0,087 \\
0,656 \\
\end{array}$ & 0,162 \\
\hline
\end{tabular}




\section{Discussão}

A placenta é um órgão que exerce importante função no transporte de nutrientes da gestante para o feto. A placenta também pode atuar como um veículo de transporte de metais pesados como o chumbo, permanecendo, no entanto, desconhecidas as quantidades transferidas para o feto.

A contaminação por chumbo interfere negativamente na antropometria do recém-nascido e na maturação fetal, apresentando um impacto no crescimento e desenvolvimento da criança, assim como na morbidade e mortalidade (Kramer et. al., 1990). Os efeitos neurotóxicos do chumbo, mesmo frente a uma baixa exposição, podem ocasionar uma diminuição da inteligência, uma menor capacidade de memorização e diminuição da função visual (Torres-Sánchez et. al., 1999; Raghunath et. al., 2000; Sanin et. al., 2001).

Embora as populações vulneráveis estejam expostas a baixos niveis de chumbo, esta contaminação, pode constituir um fator de risco, tendo em conta que a vida média do chumbo estocado nos ossos é de 12 anos, principalmente nas mulheres que vivem em zonas industriais ou trabalham em indústrias metalúrgicas manipuladoras de chumbo. Existem algumas situações onde o chumbo estocado nos ossos é mobilizado para a corrente sangüinea como no caso da gestação ou lactação, passando finalmente para o recém-nascido (Gomaa et. al., 2002).

\subsection{Caracteristicas das parturientes}

O grupo de parturientes considerado neste estudo apresentou caracteristicas sócio-econômicas compatíveis com as de populações pertencentes a estratos menos favorecidos. Foram parturientes atendidas em sua totalidade pelo Sistema Único de Saúde - SUS (100\%), em sua maioria eram donas de casa $(94,5 \%)$, com uma renda "per capita" mensal igual ou inferior a 0,25 salário mínimo (52,7\%). Tais características, colocam o grupo estudado entre as faixas populacionais mais expostas ao risco de desenvolver problemas de saúde. 
As parturientes se distribuiram na faixa etária de 14 a 36 anos, com predominância entre 20 a 33 anos, o que caracteriza um grupo de menor risco obstétrico. Aproximadamente $22 \%$ das parturientes eram adolescentes.

Estes resultados foram semelhantes aos encontrados por Rondó (1993), estudando um grupo de parturientes atendidas pelo SUS em Campinas, que encontrou $21,6 \%$ de adolescentes grávidas em um grupo que variou entre 14 e 42 anos. Cassana (1998), analisando um grupo de gestantes no municipio de Santo André, atendidas pela Fundação de Assistência à Infância - FAISA, encontrou $21 \%$ de adolescentes grávidas.

A análise das características obstétricas demonstrou que a maioria das parturientes $(61,8 \%)$ eram multigestas e tiveram parto normal $(96,4 \%)$. Silbergeld (1991) e Symanski e Hertz-Picciotto (1995) estudaram a relação entre o nivel sangüineo de chumbo com a história obstétrica. Observaram que o aumento da plumbemia era maior nas mulheres primigestas do que nas mulheres multigestas Concluiu-se que a gravidez ao causar desmineralização óssea, mobiliza o chumbo depositado nos ossos para a corrente sangüinea, elevando os niveis de chumbo sangüíneo na parturiente e colocando em risco a saúde do recém-nascido.

O uso de suplementos contendo minerais foi referido por $31 \%$ e $9,1 \%$ das parturientes para ferro e cálcio respectivamente. Resultados similares foram encontrados por Rondó (1993) que observou que 35\% das parturientes estudadas em Campinas tomavam multivitaminas ou compostos contendo ferro. Arruda (1997) em estudo realizado em Recife, encontrou $76,0 \%$ de parturientes que consumiram antianêmicos durante o curso da gestação. Cassana (1998) observou que $62,1 \%$ das parturientes atendidas em Santo André referiam a ingestão de suplemento de ferro por 13 semanas ou mais de gestação.

Boa parte das parturientes avaliadas neste estudo $(47,3 \%)$ encontram-se na faixa de normalidade de IMC de 18,5 a 24,9 , sendo que apenas $5,5 \%$ foram caracterizadas como obesas. Domene et. al. (1999) avaliaram o estado nutricional de 121 parturientes do municipio de Campinas-SP e observaram que a maioria das 
parturientes $(55,5 \%)$ encontrava-se na faixa da normalidade e $13,2 \%$ apresentava obesidade. Nucci et. al. (2001) estudaram 5,564 parturientes atendidas em serviços de pré-natal geral do SUS em seis capitais brasileiras e verificaram que $69,6 \%$ das parturientes encontravam-se na faixa de normalidade de IMC e 5,5\% das parturientes eram obesas.

\subsection{Caracteristicas dos recém-nascidos}

Foi constatado que $92,7 \%$ dos recém-nascidos envolvidos neste estudo nasceram com peso adequado e 5,5\% apresentaram baixo peso ao nascimento. De acordo com Pitard-III (1993), são considerados recém-nascidos de baixo peso todos aqueles que nascem com peso inferior a $2500 \mathrm{~g}$, independente da causa e da duração da gestação. Como este estudo envolveu apenas recém-nascidos a termo, pode-se dizer que os $5,5 \%$ que apresentaram baixo peso ao nascimento, provavelmente tiveram retardo de crescimento intrauterino.

\subsection{Níveis sangüíneos de chumbo em parturientes e recém-nascidos (cordão umbilical)}

A gravidez é um processo de constantes mudanças no organismo materno. Ocorrem alterações no metabolismo do cálcio assim como do ferro, no volume e na composição do sangue, alterando a cinética do chumbo com conseqüente interferência na plumbemia. A redução nos níveis de ferro e cálcio da parturiente não ocorre apenas em decorrência da expansão do volume sangüineo, também deve ser considerada a constante transferência destes minerais para a placenta e, posteriormente, para o feto, principalmente no último trimestre de gestação, onde se incrementam os requerimentos tanto de ferro como de cálcio (Lagerkvist 1996a; Allen, 1997).

Souza et. al. (2002) afirmaram que o volume sangüineo matemo aumenta durante o primeiro trimestre, se expande mais rapidamente durante o segundo trimestre, continua a aumentar, em ritmo menor, no terceiro trimestre, estacionando-se nas últimas semanas da gravidez. Este incremento do volume sangüíneo resulta do 
aumento do plasma e hemácias, levando à hipervolemia e hemodiluição, diminuindo os valores do hematócrito e da hemoglobina.

A relação dos metabolismos do cálcio e do chumbo é complexa. Estes dois elementos têm diferentes taxas de reabsorção óssea, podendo o chumbo ser mobilizado em muito maior escala que o cálcio. Dependendo da magnitude do reservatório ósseo, apenas uma pequena quantidade de chumbo precisaria ser mobilizada para que fossem atingidas concentraçōes tóxicas nos tecidos moles como no fígado e nos rins (Rabinowitz, 1991).

\subsubsection{Niveis de chumbo das parturientes em relação ao foco de contaminação}

No presente estudo, quando comparamos as médias dos niveis sangüineos de chumbo das parturientes de acordo com as distâncias em relação à fonte de contaminação de chumbo, notou-se que as médias mais elevadas pertenciam as parturientes que moravam mas perto à industria metalúrgica manipuladora de chumbo.

Graziano et. al. (1990) avaliaram 1502 gestantes expostas e não expostas à contaminação por chumbo em duas cidades da lugoslávia. Concluiram que os níveis sangüineos de chumbo das gestantes moradoras na cidade onde existia uma indústria metalúrgica eram substancialmente mais elevados que os niveis sangüineos de chumbo do grupo controle. Supõe-se então que as populações mais expostas à contaminação por chumbo encontram-se nas proximidades dos focos de contaminação.

Khera et. al. (1990) estudaram os niveis de chumbo no sangue e ossos de natimortos, assim como no sangue, ossos e tecido placentário de mulheres trabalhadoras numa indústria matalúrgica manipuladora de chumbo numa região da Inglaterra, encontrando uma forte correlação significativa entre o nivel sangüíneo de chumbo das parturientes e seus recém-nascidos $(r=0,60)$. Concluiu-se que mulheres em idade reprodutiva não deveriam ser empregadas por este tipo de indústria e ainda que gestantes deveriam ser proibidas de realizar trabalhos desta magnitude. 
Amitai et. al. (1999) compararam duas populações de 156 gestantes e seus respectivos recém-nascidos na cidade de Kazakhstan, expostas e não expostas à contaminação por chumbo de acordo com a distância entre o local de moradia e a indústria metalúrgica. Observou-se que existia uma relação inversamente proporcional entre os elevados niveis sangüineos de chumbo e a proximidade com o foco de contaminação.

Existe um reduzido número de trabalhos na literatura avaliando a relação entre contaminação por chumbo em gestantes e distância do local de moradia. Um estudo realizado em Santo Amaro da Purificação-BA com 555 crianças de 1 a 9 anos de idade, que residiam a 900 metros ao redor da indústria metalúrgica, mostrou que a distância do domicilio da criança á indủstria, foi a variável mais fortemente associada à variação dos niveis de chumbo (Carvalho et. al., 1987).

Em estudo realizado com 120 crianças holandesas de 2 a 3 anos de idade, residindo a menos de $1 \mathrm{~km}$ de uma indústria metalúrgica observou-se média de níveis sangüineos de chumbo de $19,7 \mu \mathrm{g} / \mathrm{dL}$. Outro estudo realizado com 172 crianças americanas de 1 a 9 anos de idade, residentes a menos de $1,6 \mathrm{~km}$ de uma indústria metalúrgica, detectou níveis sangüineos de chumbo superiores a $79,9 \mu \mathrm{g} / \mathrm{dL}$ em $98 \%$ dessas crianças. Finalmente um estudo realizado com 110 crianças belgas de 10 a 13 anos de idade residindo a menos de $1 \mathrm{~km}$ de uma indústria metalúrgica verificou uma média de niveis sangüineos de chumbo de $30,2 \mu \mathrm{g} / \mathrm{dL}$. Concluiu-se através desses estudos, que a distância entre o domicilio e o foco de contaminação está associada com os elevados niveis sangüineos de chumbo nestas populações (Carvalho et. al., 1987).

Em estudo realizado com 263 crianças de 1 a 9 anos de idade, residentes a menos de 900 metros de indústria metalúrgica na cidade de Santo Amaro da Purificação na Bahia, avaliando os niveis de chumbo no cabelo, Observou-se que os niveis deste metal no cabelo aumentaram proporcionalmente ao maior tempo de residência nesta área (Carvalho et. al., 1989). Portanto, conclui-se pelo presente estudo que a contaminação por chumbo, apesar de ter sido avaliada através de outro 
indicador biológico, também comprova a associação entre a distância do local de moradia e o foco de contaminação.

\subsubsection{Relação dos niveis de chumbo das parturientes e seus respectivos recém- nascidos}

No presente estudo verificou-se que os recém-nascidos apresentaram niveis de chumbo inferiores aos das parturientes, independente do método utilizado no diagnóstico da contaminação por chumbo.

Foi observada boa correlação entre os níveis de chumbo da parturiente e recém-nascido tanto através do método da AA-FG como do método de eletroquimica"LeadCare" ( $r=0,86$ e $r=0,73$, respectivamente).

Estes achados sugerem que a placenta não é capaz de inibir a passagem do chumbo para o feto, mesmo se a exposição for baixa, confirmando a hipótese que $o$ chumbo presente no organismo da gestante atravessa livremente as estruturas placentárias, atingindo o feto.

Dados similares foram encontrados por vários autores, quando comparados os niveis sangüineos de chumbo materno e do cordão umbilical $(0,63 \leq r \leq 0,83)$, com valores menores no cordão umbilical (Ong et. al., 1985; Korpela et. al., 1986; Troster, 1986; Hernández-Avila et. al., 1997; Amitai et. al., 1999; Campagna et. al., 1999; Navarrete et. al., 2000; Raghunath et. al., 2000).

No presente estudo, não foram detectados niveis muito elevados de chumbo no sangue das parturientes avaliadas. No entanto, estudos epidemiológicos tem demostrado que mesmo os niveis de chumbo inferiores à $10 \mu \mathrm{g} / \mathrm{dL}$ (ponto de corte considerado de risco para contaminação por chumbo) estão associados com alteraçōes nos sistemas neurocognitivo (deficiências neurocomportamentais e diminuição do coeficiente de inteligência), visual, motor e auditivo de crianças $\mathrm{WHO}$, 1995; Millstone, 1997; Azcona et. al., 2000; Furman e Laleli, 2001). 
5.3.3. Associação entre os niveis sangüineos de chumbo e peso, hemoglobina e consumo de cálcio das parturientes

Com relação aos resultados das análises dos modelos de regressão linear multivariada dos niveis sangüineos de chumbo das parturientes, descrevemos a seguir o modelo final.

As variáveis independentes de maior significância para o chumbo foram o peso, a hemoglobina e o consumo de cálcio, observando-se uma correlação inversamente proporcional entre ambas.

Schell et. al. (2000) estudaram associação entre os niveis sangüineos de chumbo das parturientes e dos recém nascidos com o peso das parturientes e consumo alimentar. Verificou-se que existe uma relação inversamente proporcional entre o peso e consumo de cálcio das parturientes e os niveis de chumbo. Concluiu-se que esta associação indica que existe uma complexa inter-relação entre o chumbo, a dieta e o estado nutricional das parturientes.

Navarrete et. al. (2000) analisaram os niveis sangüineos de chumbo das parturientes e dos recém nascidos e encontraram uma associação inversa entre os niveis de chumbo e o consumo de cálcio. Este achado também foi reportado por outros estudos realizados no México (Romieu et. al., 1994; Farias et. al., 1996; Rothenberg et. al., 1996), concluindo-se que o consumo de cálcio pode ser considerado como fator protetor, pois o cálcio poderia diminuir a absorção do chumbo através do trato digestivo por uma ação competitiva à nivel de receptores gastrointestinais.

Rothenberg et. al. (2000) avaliaram os niveis sangüineos de chumbo de 311 mulheres no último trimestre de gestação e dois meses após o parto. Estas gestantes eram migrantes da América Latina para a cidade de Los Angeles nos Estados Unidos. Observaram que o insuficiente consumo de cálcio assim como o uso de louça vitrificada, influenciou o aumento dos niveis sangüineos de chumbo tanto antes como após o parto. 
Johnson (2001) estudou a relação entre o consumo de cálcio e os niveis de chumbo matemo em 195 gestantes. O consumo de cálcio foi estratificado da seguinte maneira: $\leq 600 \mathrm{mg} / \mathrm{dia},>600$ e $<1000 \mathrm{mg} / \mathrm{dia},>1000$ e $\leq 2000 \mathrm{mg} / \mathrm{dia}$, e $>2000 \mathrm{mg} / \mathrm{dia}$. $O$ incremento de chumbo sangüineo, durante a gestação, esteve inversamente relacionado com o consumo baixo de cálcio. Os níveis de chumbo sangüíneo diminuíram conforme aumentava o consumo de cálcio. Assim temos que na $36^{\mathrm{a}}$ semana da gestação os niveis sangüineos de chumbo foram $23 \%$ menores para o consumo de cálcio $>2000 \mathrm{mg} /$ dia quando comparados com o consumo de cálcio $\leq$ $600 \mathrm{mg} / \mathrm{dia}$, Os autores observaram que o fator de proteção para os elevados níveis sangüineo de chumbo era o elevado consumo de cálcio. O cálcio é mobilizado dos ossos maternos para o feto, principalmente após a segunda metade da gestação, servindo como suporte do crescimento da estrutura óssea do feto depois do nascimento.

Recentemente em estudo prospectivo realizado por Schell et al. (2003) com 83 gestantes da cidade de Nova York, durante os três trimestres de gravidez, observou-se que existe uma relação inversamente proporcional entre niveis elevados de chumbo, baixo peso da gestante, limitados estoques de ferro e consumo de cálcio inferior ao recomendado pelas RDAs (Recommended Dietary Allowances). Concluiu-se que deveriam ser aplicadas possiveis intervençōes nas populações de alto risco para evitar os estragos desta contaminação.

Alguns trabalhos também tem documentado uma forte correlação entre elevação dos niveis sangüineos de chumbo e declínio dos niveis do hematócrito, assim como da hemoglobina, tanto durante a gravidez como na infância (Watson et. al., 1986; Hu et. al., 1994; Bradman et. al., 2001).

Hammad et. al. (1996) acompanharam 299 crianças desde os 9 meses de idade até os 5 anos de idade, atendidos no ambulatório pediátrico da Universidade Johns Hopkins nos Estados Unidos. Foram avaliados através do nivel sangüineo de chumbo, considerando-se também como variável de interesse o consumo de ferro. Verificou-se uma associação inversa entre os niveis sangüineos de chumbo e o consumo de ferro. 
Concluiu-se que os niveis sangüineos de chumbo estão inversamente relacionados com o consumo de ferro. Portanto, um elevado consumo de ferro através da dieta, poderia atuar como fator protetor à contaminação por chumbo, principalmente em zonas altamente poluidas por este metal, assim como nas populações mais vulneráveis.

Counter et. al. (2000) investigaram a relação entre os niveis sangüineos de chumbo e os niveis de hemoglobina em 88 crianças de 2 até 5 anos. Uma correlação inversamente proporcional foi observada entre ambas as variáveis $(r=-0,29)$. Concluiuse que os elevados niveis sangüineos de chumbo podem provavelmente acarretar a presença de anemia.

Suplido e Ong (2000) determinaram os níveis sangüineos de chumbo e os niveis de hemoglobina $(\mathrm{Hb})$ em 40 trabalhadores de uma indústria de reciclagem de baterias, 16 trabalhadores de uma oficina mecânica, e 20 crianças moradoras nas imediações destas indústrias. Noventa por cento $(90 \%)$ dos individuos com elevados niveis sangüíneos de chumbo $(\mathrm{Pb})$ apresentaram também anemia $(\mathrm{Pb}>40 \mu \mathrm{g} / \mathrm{dL} ; \mathrm{Hb}<$ $11,5 \mathrm{~g} / \mathrm{dL}$ ). Foi observada uma correlação inversamente proporcional entre $\mathrm{Pb}$ e $\mathrm{Hb}$ ( $\mathrm{r}=$ $-0,21)$.

As deficiências dos estoques de ferro não só incrementam o risco da absorção elevada do chumbo, mas também aumentam a retenção do chumbo nos tecidos, assim como a toxicidade deste metal. Estas investigaçōes sugerem que há uma necessidade urgente da intervenção de programas para detecção precoce de contaminação por chumbo nas populações vulneráveis, objetivando-se uma redução da prevalência dos niveis sangüineos elevados de chumbo, assim como a prevenção da deficiência de ferro nas populações de maior risco, através de suplementação (Kaul, 1999; Wright et. al., 2003).

Baghurst et. al. (1997) realizaram um estudo com 500 gestantes moradoras próximo a uma indústria metalúrgica na cidade de Port Pirie na Austrália, observandose que as gestantes que receberam suplementação de ferro durante a gravidez apresentaram niveis de chumbo inferiores as gestantes que não foram suplementadas. 
O Centers for Disease Control (CDC), centro de referência de controle de contaminação por chumbo, recomenda um consumo adequado de cálcio e ferro, como uma das medidas preventivas para a toxicidade de chumbo. Em casos onde existe uma deficiência de cálcio ou ferro, deve ser realizada a suplementação com ambos os nutrientes pois tem sido observada a relação entre a deficiência de ferro e/ou cálcio com dano do desenvolvimento neurocomportamental em populaçōes expostas à contaminação por chumbo (Goyer, 1997; Hernández-Avila et. al., 1997).

\subsubsection{Associação entre os niveis sangüíneos de chumbo e comprimento e peso dos recém-nascidos}

Com relação aos resultados das análises dos modelos de regressão linear multivariada dos niveis sangüineos de chumbo dos recém-nascidos, descrevemos a seguir o modelo final.

As variáveis independentes de maior significância para o chumbo foram o comprimento e o peso, verificando-se também uma correlação inversamente proporcional entre ambas.

Gonzáles-Cossio et. al. (1997) verificaram resultados similares aos do presente estudo, observando uma correlação inversa entre os niveis de chumbo das parturientes e o peso dos recém-nascidos, concluindo que o retardo do crescimento intra-uterino, pode ter sido ocasionado pela mobilização do chumbo das parturientes para seus respectivos recém-nascidos e não pela própria prematuridade, colocando em risco à saúde dos recém-nascidos.

Torres-Sánchez et. al. (1999) estudaram parturientes para determinar os riscos de recém-nascidos pré-termo (< 37 semanas) em relação aos níveis sangüineos de chumbo no cordão umbilical. Verificou-se que a freqüência dos recém-nascidos prétermo foi três vezes mais elevado nas parturientes com niveis sangüíneos de chumbo igual ou acima de $5,1 \mu \mathrm{g} / \mathrm{dL}$, quando comparadas com as parturientes com niveis sangüineos de chumbo inferiores à $5,1 \mu \mathrm{g} / \mathrm{dL}$. Estes resultados sugerem que a 
exposição intra-uterina ao chumbo, pode estar associado com recém-nascidos prétermo.

Sanin et. al. (2001) avaliaram o crescimento pós-natal dos recém-nascidos amamentados com leite materno em relação aos niveis de chumbo da mãe. Os niveis sangüíneos de chumbo nos recém-nascidos foram inversamente associados com o ganho de peso dos mesmos. Crianças com aleitamento matemo exclusivo tiveram ganho de peso significativamente elevado, porém este ganho de peso diminuiu com o incremento dos niveis de chumbo, pois alguns estudos tem reportado a mobilização do chumbo durante a lactação (Sowers et. al., 1993; Sowers et. al., 1995; Krebs et. al., 1997; Téllez-Rojo et. al., 2002).

As concentrações de chumbo no leite matemo são baixas, portanto, a exposição à contaminação por chumbo na parturiente não é razão para deixar de amamentar o recém-nascido, pois os beneficios do aleitamento matemo são bastante conhecidos. Sugere-se então que sejam realizadas e/ou estudadas outras intervençōes para a redução da exposição à contaminação por chumbo nesta população (Sowers et. al., 1993; Sowers et. al., 1995; Krebs et. al., 1997, Sanín et. al., 2001).

Sabe-se que a exposição ambiental à contaminação por chumbo antes da gravidez, pode ser responsável pelo acúmulo de chumbo no organismo humano, principalmente nos ossos matemos. Alguns mecanismos psicológicos e/ou hormonais podem agir nos estoques de chumbo ósseo durante a gestação, contribuindo para a exposição fetal. Outros fatores durante esta etapa da vida, tais como a ocupação da mãe, uso de tabaco e/ou álcool, ingestão de água elou dieta contaminadas por chumbo, tem um papel muito importante na exposição do recém-nascido (Sanin et. al., 2001).

Recentemente foi demostrado que seqüelas neurocomportamentais, provocadas através da intoxicação materna, podem ser observadas na segunda geração de filhos (Trombini et. al., 2001). Os lactentes avaliados neste estudo, apesar de mostrarem baixos niveis de chumbo sangüineo, compreendidos entre $5,5 \mu \mathrm{g} / \mathrm{dL}$ e $8,0 \mu \mathrm{g} / \mathrm{dL}$, apresentaram sinais de intoxicação. Recomenda-se que se deva realizar 
uma análise completa das condiçōes do ambiente doméstico e de trabalho, com a finalidade de se identificar e eliminar as possiveis fontes de contaminação (Godinho et. al., 2001).

Embora os niveis médios de chumbo sangüineo tenham diminuido na população em geral, os efeitos da contaminação por chumbo ainda necessitam atenção especial (Hemández-Avila e Palazuelos-Rendón,1995). A elevação do chumbo sangüineo no feto pode ocasionar abortamento, prematuridade, morte fetal ou alterações neurocognitivas na vida pós-natal (Calderón et. al., 1996).

A contaminação por chumbo é extremamente grave principalmente em crianças, e provavelmente muito mais preocupante no caso de contaminação do feto, sendo passivel de prevenção pela adoção de processos de higiene industrial, proibição da adição de chumbo tetraetilico na gasolina e equipamentos de proteção coletiva (ATSDR, 1990).

Em geral, a maior exposição ocorre em trabalhadores de indústrias, que utilizam chumbo nos seus processos de trabalho como por exemplo as fábricas de baterias, de tintas, gráficas e em trabalhadores envolvidos com atividades de soldagem e fundição. Por outro lado, uma maior atenção deveria ser dirigida às mulheres em idade fértil, expostas ocupacionalmente ao chumbo, ou que residem próximo à fonte poluidora de chumbo para o ambiente.

Entretanto, o conhecimento da possibilidade de lesões à saúde, ocasionadas por exposição a baixos niveis de chumbo, precisa ser mais difundido, uma vez que a prevenção è de grande importância, dada a irreversibilidade clínica das lesões ocasionadas pelo chumbo.

Sendo o presente, um estudo de tipo transversal, se vê limitado pelos aspectos metodológicos assim como pelos escassos trabalhos desenvolvidos sobre a cinética do chumbo na gravidez. Portanto surge a necessidade de um maior número de estudos nessa linha de pesquisa, pois os beneficios obtidos através do conhecimento da 
cinética do chumbo, no binômio mãe recém-nascido, poderiam minimizar os danos causados à saúde pela intoxicação crônica desse metal pesado. 


\section{Conclusões}

A análise dos niveis sangüineos de chumbo das parturientes e recém-nascidos realizada neste estudo permitiu as seguintes conclusões:

- As médias dos niveis sangüíneos de chumbo das parturientes que moram perto da fonte de contaminação foram maiores que as médias dos niveis sangüineos de chumbo no sangue das parturientes que moram à distância média ou longe.

- Houve uma relação estatisticamente significativa entre os níveis sangüíneos de chumbo das parturientes e seus respectivos recém-nascidos, independente do método utilizado para a determinação de chumbo.

- Os fatores correlacionados negativamente com os niveis sangüíneos de chumbo das parturientes foram: peso, hemoglobina e consumo de cálcio.

- Os fatores correlacionados negativamente com os níveis sangüíneos de chumbo dos recém-nascidos foram: peso e comprimento. 


\section{Referências}

Aguilar-Madrid G, Piacitelli GM, Juárez-Pérez CA, Vázquez-Grameix JH, Hu $H$, Hernández-Avila M. Exposición ocupacional a plomo inorgánico en una imprenta de la ciudad de México. Salud Pública Méx 1999; 41: 42-54.

Ahlgren L, Haeger-Aronsen B, Mattsson S, Schutz A. In-vivo determination of lead in the skeleton after occupational exposure to lead. Br J Ind Med 1980; 37: 109-13.

Allen LH. Pregnancy and iron deficiency: unresolved issues. Nutr Rev 1997; 55 (4): 91101.

Amitai $Y$, Koifman M, Orenbayev T, Almog S, Tepferberg M, Dimitriev A, Vakhlis L. Prenatal exposure in a highly polluted area in Kazakhstan: effect on mental development. J Toxicol Clin 1999; 37: 402.

Anjos JA. Estratégias para remediação de um sítio contaminado por metais pesados: estudo de caso. São Paulo; 1998. [Dissertação de Mestrado - Escola Politécnica da Universidade de São Paulo].

Arruda IKG. Deficiência de ferro, de folato e anemia em gestantes atendidas no Instituto Materno Infantil de Pernambuco: magnitude, fatores de risco e algumas implicações nos seus conceptos. Recife; 1997. [Tese de Doutorado - Universidade Federal de Pernambuco].

ASEM - NPBI Produtos Hospitalares. Manual HemoCue® blood hemoglobin photometer . São Paulo; s.d.

Association of Official Analytical Chemists. Official methods of analysis of the Association of Official Analytical Chemists. $16^{\text {th }}$ ed. Washington, DC: AOAC; 1995.

[ATSDR] Agency for Toxic Substances and Disease Register. Toxicological profile for lead. Washington, DC: ATSDR; 1990. 
Audrey S, Takser L, Andre M, Martin S, Donna M, Genevieve A, et. al. A comparative study of manganese and lead levels in human umbilical cords and maternal blood from two urban centers exposed to different gasoline additives. Sci Total Environ 2002; 290: $157-64$.

AVIV Bimomedical. Manual automatic ZP hematofluorometer model 206 serial number A-834. Lakewood; 1998.

Azcona M, Rothenberg S, Schnaas L, Romero M, Perroni E. Niveles de plomo en sangre en niños de 8 a 10 años y su relación con la alteración en el sistema visomotor y del equilibrio. Salud Pública Méx 2000; 42: 279-87.

Baghurst PA, McMichael AJ, Vimpani GV, Robertson EF, Clark PD, Wigg NR. Determinants of blood lead concentrations of pregnant women living in Port Pirie and surrounding areas. Med J Aust 1997; 146: 69-73.

Baranowska I. Lead and cadmium in human placentas and maternal and neonatal blood(in the heavily polluted area) measured by graphite furnace atomic absorption spectrometry. Occup Environ Med 1995; 52:229-32.

Barry P, Mossman D. Lead concentrations in human tissues. Br J Ind Med 1970; 27 : 339- 51.

Berlin A, Schaller KH. European standardized method for the determination of $\delta$ aminolevulinic acid deshydratase activity in blood. Z Klin Chem Klin Biochem 1974; 12:389-90.

Blake K, Mann M. Effect of calcium and phosphoruson the absorption for lead in man. Environ Res 1983; 30: 188-94.

Bradman A, Eskenazi B, Sutton P, Athanasoulis M, Goldman LR. Iron deficiency association with higher blood lead in children living in contaminated environments. Environ Health Perspect 2001; 109: 1079-84. 
Buchet J, Lauwerys R, Roels $H$, Hubermont G. Mobilization of bone mineral during pregnancy in rats. Int Arch Occup Environ Health 1977; 40: 33-6.

Calderón J, Hemández $C$, Valdés $B$, Maldonado $M$, López A. Evolution of lead toxicity in a population of children. Hum Exp Toxicol 1996; 15: 376-82.

Campagna D, Huel G, Girard F, Sahuquillo J, Blot P. Environmental lead exposure and activity of $\delta$-aminolevulinic acid dehydratase (ALA-D) in maternal and cord blood Toxicology 1999; 134: 143-52.

Campagna D, Huel G, Hellier G, Girard F, Sahuquillo J, Fagot-Campagna A, et. al. Negative relationships between erythrocyte Ca-pump activity and lead levels in mothers and newborns. Life Sci 2000; 68: 203-15.

Carvalho FM, Tavares TM, Souza SP, Linhares P. Absorção e intoxicação por chumbo e cádmio em pescadores da região do rio subaé. Ciênc Cult 1983; 35: 360-6.

Carvalho FM, Silvany Neto AM, Lima MEC, Tavares TM, Azaro MGA, Quaglia GMC. Chumbo e cádmio no sangue e estado nutricional de crianças, Bahia, Brasil. Rev Saúde Pública 1987; 21: 44-50.

Carvalho FM, Silvany Neto AM, Chaves MEC, Melo AMC, Galvão AL, Tavares TM. Chumbo e cádmio em cabelo de crianças de Santo Amaro da Purificação, Bahia. Ciênc Cult 1989; 41: 646-51.

Cassana LMN. Intervenção nutricional no controle da deficiência de ferro em gestantes da rede básica de saúde. São Paulo; 1998. [Tese de Doutorado Faculdade de Saúde Pública da Universidade de São Paulo].

[CDC] Centers for Disease Control. Preventing lead poisoning in young children: a statement by the centers for disease control-october 1991. Centers for Disease Control, U.S. Department of Health and Human Services, Atlanta, GA; 1996. 
[CETESB] Companhia de Tecnologia de Saneamento Ambiental. Construção de poços de monitoramento de aqüifero freático- procedimentos. CETESB, São Paulo; 1987.

Christoffersson J, Schutz A, Ahlgren L, Haeger-Aronsen B, Mattson S, Skerfving S. Lead in finger-bone analysed in vivo in active and retired lead workers. Am J Ind Med 1984; 6: 447-57.

Cordeiro R, Lima Filho E, Salgado P. Reajustando o limite de tolerância biológica aplicada à plumbemia no Brasil. Cad Saúde Pública 1996; 12: 455-63.

Counter SA, Buchanan LH, Ortega F, Rifai N. Blood lead and hemoglobin levels in andean children with chronic lead intoxication. Neurotoxicology 2000; 21: 301-8.

Domene SM, Zabotto CB, Meneguello R, Galeazzi MA, Taddei JA. Perfil nutricional de crianças e suas mães em bolsões de pobreza do município de Campinas, SP-1996. Rev Nutr Campinas 1999; 12: 183-9.

Erhardt J. NutriSurvey for window 95 [computer program] Hohenheim (DE): University of Hohenheim; 1999.

ESA, AndCare Inc. LeadCare. Dunham, USA; s.d.

Farias P, Borja-Aburto VH, Ríos C, Hertz-Picciotto I, Rojas-López M, Chávez-Ayala R. Blood lead levels in pregnant women of high and low socioeconomic status in Mexico City . Environ Health Perspect 1996, 104: 1070-4.

Fergusson J. The heavy metal elements-chemistry, environmental impact and health effects. New York: Pergamon Press; 1990.

Frenz P, Vega J, Marchetti N, Torres J, Kopplin E, Delgado I, Vega F. Exposición crónica a plomo ambiental en lactantes chilenos. Rev Med Chile 1997; 125: 1137-44. 
Fullmer C, Edelstein S, Wasserman R. Lead-binding properties of intestinal calciumbinding proteins. J Biol Chem 1985; 260: 6816-9.

Fundação IBGE. Estudo Nacional da Despesa Familiar-ENDEF: tabelas de composição de alimentos. $4^{\mathrm{a}}$ ed. Rio de Janeiro; 1996.

Fundação IBGE. Censo demográfico 2000. [On line]. Disponível em:

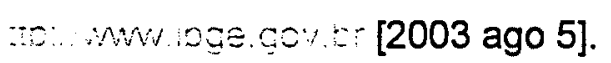

Furman A, Laleli M. Maternal and umbilical cord blood levels: an Istanbul study. Arch Environ Health 2001; 56: 26-8.

Godinho AF, Vassilief I, Almeida de AA, Silva da AG, Aguiar de DC. Intoxicação por chumbo em bebês lactentes em três casos de exposição maternal. Salusvita 2001; 20 (3): 11-8.

Goldman RH, White R, Kales S, Hu H. Lead poisoning from mobilization of bone stores during thyrotoxicosis. Am J Ind Med 1993; 24: 1-8.

Gomaa A, Hu H, Bellinger D, Schwartz J, Tsaih SW, Gonzáles-Cossio T, et. al. Maternal bone lead as an independent risk factor for fetal neurotoxicity: a prospective study. Pediatrics 2002; 110 : 110-8.

Gonzáles-Cossio T, Peterson K, Sanin L, Fishbein E, Palazuelos E, Aro A, HernándezAvila $\mathrm{M}, \mathrm{Hu} \mathrm{H}$. Decrease in birth weight in relation to maternal bone-lead burden. Pediatrics 1997; 100: 856-62.

Goyer RA. Toxic and essential metal interactions. Ann Rev Nutr 1997; 17: 37-50.

Graziano JH, Popovac D, Factor-Litvak P, Shrout P, Kline J, Murphy MJ, et. al. Determinants of elevated blood lead during pregnancy in a population surrounding a lead smelter in Kosovo, Yugoslavia. Environ Health Perspect 1990; 89: 95-100. 
Guidi B, Ronchi S, Ori E. Lead concentrations in breast milk of women living in urban areas compared with women living in rural areas. Pediatr Med Chir 1992; 14: 611-6.

Gulson BL, Gray B, Mahaffey KR, Jameson CW, Mizon KJ, Patison N, Korsch MJ. Comparison of rates of exchange of lead in the blood of newly born infants and their mothers with lead from their current environment. J Lab Clin Med 1999; 133: 171-8.

Hammad TA, Sexton M, Langenberg P. Relationship between blood lead and dietary iron intake in preschool children. Ann Epidemiol 1996; 6: 30-3.

Heard M, Chamberlain A. Effect of mineral and food on uptake of lead from gastrointestinal tract in humans. Hum Toxicol 1982; 1: 411-5.

Hernández-Avila M, Palazuelos-Rendón E. Intoxicación por plomo en México: prevención y control. Cuemavaca. Perspect Salud Pública 1995; 21: 257-88.

Hemández-Avila M, Sanin L, Romieu I, Palazuelos E, Tapia- Conger R, Olaiz G, Rojas $\mathrm{R}$, Navarrete J. Higher milk intake during pregnancy is associated with lower matemal and umbilical cord lead levels in postpartum women. Environ Res 1997; 74: 116-21.

Hu H, Watanable H, Payton M, Korrick S, Rotnitzky A. The relationship between bone lead and hemoglobin. JAMA 1994; 272: 1512-7.

Hulley SB, Cummings SR. Designing clinical research: an epidemiologic approach. Baltimore: Williams \& Wilkins; 1998.

Johnson MA. High calcium intake blunts pregnancy-induced increases in maternal blood lead. Nutr Rev 2001; 59: 152-6.

Kaul B. Lead exposure and iron deficiency among Jammu and New Delhi children. Ind J Pediatr 1999; 66: 27-35. 
Keller C, Dohoerty R. Bone lead mobilization in lactating mice and lead transfer to suckling offspring. Toxicol Appl Pharmacol 1980; 55: 220-8.

Khera AK, Wibberley DG, Dathan JG. Placental and stillbirth tissue lead concentrations in occupationally exposed women. Br J Ind Med 1990; 37: 394-6.

Korpela H, Loueniva R, Yrjanheikki E, Kauppila A. Lead and cadmium concentration in maternal and umbilical cord blood, amniotic fluid, placenta, and amniotic membranes. Am J Obstet Gynecol 1986; 155: 1086-9.

Krachler M, Rossipal E, Micetic-Turk D. Trace element transfer from the mother to the newborn investigations of triplets of colostrum, maternal and umbilical cord sera. Eur $J$ Clin Nutr 1999; 53: 486-94.

Kramer $M$, Olivier $M$, McLean $F$. Impact of intrauterine growth retardation and body proportionality on fetal and neonatal outcome. Pediatrics 1990; 86: 707-13.

Krebs NK, Reidinger CJ, Robertson AD, Brenner M. Bone mineral density changes during lactation: maternal, dietary and biochemical correlates. Am J Clin Nutr 1997; 65: 1738-46.

Lagerkvist B, Ekesrydh S, Englyst V, Nordberg G, Sorderberg HÁ, Wiklund DE. Increased blood lead and decreases calcium levels during pregnancy: a prospective study of swedish women living near a smelter. Am J Public Health 1996a; 86: 124752.

Lagerkvist B, Sandberg S, Jin T, Nordberg G. Is placenta a good indicator of cadmium and lead exposure?. Arch Environ Health 1996b; 51: 389-94.

Mahaffey K, Annest J. Association of EP with blood lead level and iron status in the Second National Health and Nutrition Examination Survey, 1976-1980. Environ Res 1986; 41: 327-8. 
Manton WI, Cook JD. High accuracy (stable isotope dilution) measurements of lead in serum and cerebrospinal fluid. Br J Ind Med 1984; 41: 313-9.

Mata L, Pérez D, Puyol P, Calvo M. Distrbution of added lead and cadmium in human and bovine milk. J Food Prot 1995; 58: 305-9.

Millstone E. Lead and public health. London: EARTHSCAN; 1997.

Ministério da Saúde. Conselho Nacional de Saúde. Brasil. Resolução 196, de 10 de outubro de 1996. [On line]. Disponivel http://www.fmtm.br/pesquisa/cep/9resolução.pdf [2003 out 3].

Moller B, Carisson LE, Johansson G, Malmqvist KG, Hammarstrom L, Berlin M. Lead levels determined in swedish permanent teeth by particle-induced $x$ - ray emission. Scand J Work Environ Health 1982; 8: 267-72.

Montoya M, Maldonado L, Landázuri P, Margain J. Determinación de plomo en la sangre del cordón umbilical en recién nacidos normales. Arch Invest Méd (Méx) 1981; $12: 457-62$.

Navarrete J, Sanín L, Escadón C, Benitez G, Olaiz G, Hernandez-Avila M. Niveles de plomo sanguineo en madres y recién nacidos derechohabientes del Instituto Mexicano del Seguro Social. Salud Pública Méx 2000; 42: 391-6.

Needleman H, Schell A, Bellinger D, Leviton A, Allred E. The long-term effect of exposure to low doses of lead in childhood. N Engl J Med 1990; 322: 83-8.

Needleman H. The current status of childhood lead toxicity. Adv Pediatr 1993; 40:12539.

Nucci LB, Schimdt MI, Duncan BB, Fuchs SC, Fleck ET, Britto MS. Nutritional status of pregnant women: prevalence and associated pregnancy outcomes. Rev Saúde Pública 2001; 35: 502-7. 
Oga Seizi. Fundamentos de toxicologia. 2 ed. São Paulo: Atheneu; 2003.

Ong CN, Phoon WO, Law Hy, Tye CY, Lim HH. Concentration of lead in maternal blood, cord blood and breast milk. Arch Dis Child 1985; 60: 756-9.

[ONU] Organización de las Naciones Unidas. Criterios de salud ambiental 3. Plomo. Programa de las naciones unidas para el medio ambiente y la organización mundial de la salud. Washington, D.C.; 1979. (ONU - Publicación cientifica, 388).

Paim, Z. Isto é Santo Amaro. 3 ed. Santo Amaro: Imprensa Oficial do Municipio de Santo Amaro; 1994.

Pitard-III WB. Classification of the low-birth-weight infant. In : Klaus MH, Fanaroff AA. Care of the high-risk neonate. Philadelphia: WB Saunders; 1993. p. 88-113.

Rabinowitz M, Wetherill G, Kopple J. Delayed appearancce of tracer lead in facial hair. Arch Environ Health 1976; 31: 220-3.

Rabinowitz M. Toxicokinetics of bone lead. Environ Health Perspect 1991; 91: 33-7.

Raghunath R, Tripathi R, Sastry V, Krishnamoorthy $T$. Heavy metals in maternal and cord blood. Sci Total Environ 2000; 250; 135-41.

Raymundo CC. Variáveis na análise de mercúrio, cádmio e chumbo em amostras de cabelo. Salvador; 1981. [Dissertação de Mestrado - Instituto de Química da Universidade Federal da Bahia].

Rhainds M, Levallois P. Umbilical cord blood lead levels in the Quebec city area. Arch Environ Health 1993; 48: 421-7.

Romieu I, Palazuelos E, Hernández-Ávila M, Ríos C, Muñoz I, Jiménez C. Sources of lead exposure in México city. Environ Health Perspect 1994; 4: 384-9. 
Rondó PHC. The influence of maternal nutritional factors on intrauterine growth retardation. London; 1993. [PhD Thesis-Faculty of Medicine-University of London].

Rothenberg SJ, Schnaas-Arrieta L, Cansino-Ortiz S, Perroni-Hernández E, De la torre $\mathrm{P}$, Neri-Mendez $\mathrm{Cl}$. Effects of lead on neurobehavioural development in the first thirty days of life. Lead exposure and child development an international assesment. Neurotoxicol Teratol 1989; 11: 85-93.

Rothenberg SJ, Karchmer S, Schnaas L, Perroni E, Zea F, Salinas V. Maternal influence on cord blood lead levels. J Epidemiol 1996; 6: 211-27.

Rothenberg SJ, Khan F, Manalo M, Jiang J, Cuellar R, Reyes S, et. al. Matemal bone lead contribution to blood lead during and after pregnancy. Environ Res 2000; 82: 8190.

Sanin LH, Gonzáles-Cossio T, Romieu I, Peterson KE, Ruiz S, Palazuelos E, et. al. Effect of maternal lead burden on infant weight and weight gain at one month of age among breastfed infants. Pediatrics 2001; 107: 1016-23.

Satin K, Neutra R, Guirguis G, Flessel P. Umbilical cord blood lead levels in california. Arch Environ Health 1991; 46: 167-73.

Schell LM, Czerwinski S, Stark AD, Parsons PJ, Gomez M, Samelson R. Matemal ethnicity/race, nutrition and anthropometry predict neonate's blood lead level. Neurotoxicology 2000; 1: 254.

Schell LM, Denham M, Stark AD, Gomez M, Ravenscroft J, Parsons PJ, et. al. Maternal blood lead concentration, diet during pregnancy, and anthropometry predict neonatal blood lead in socioeconomically disadvantaged population. Environ Health Perspect 2003; 11: 195-200. 
Schuhmacher M, Hernandez M, Domingo J, Femandez J, Llobet J. A longitudinal study of lead mobilization during pregnancy: concentrations in matemal and umbilical cord blood. J Trace Elem Electrolytes 1996; 13: 177-81.

Schutz A, Skerfving S. Effect of a short, heavy exposure to lead dust upon blood lead level, erythrocyte $\delta$-aminolevulinic acid dehydratase activity and urinary excretion of lead, $\delta$-aminolevulinic acid and coproporphyrin. Scand J Work Environ Health 1976; 3: $176-84$.

Sikorski R, Paszkowski T, Milart P, Radomanski Jr T, Szkoda J, Intrapartum levels of trace metals in matemal blood in relation to umbilical cord blood values: lead, iron, copper, zinc. Int J Gynecol Obstet 1988; 26: 213-21.

Silbergeld $\mathrm{E}$. Lead in bone: implications for toxicology during pregnancy and lactation. Environ Health Perspect 1991; 91: 62-70.

Somervaille LJ, Laird EE, Chettle DR, Scott MC. Lead body stores assesment in vivo by X-Ray fluorescence in Heavy metals in the environment. Edinburgh; 1980.

Souza Al, Filho MB, Ferreira LO. Alterações hematológicas e gravidez. Rev Bras Hematol Hemoterm 2002; 24: 29-36.

Sowers MF, Corton G, Shapiro B. Changes in bone density with lactation. JAMA 1993; 299: $3130-5$.

Sowers M, Randolph L, Shapiro B, Jannaush M. A prospective study of bone density and pregnancy after an extended period of lactation with bone loss. Obstet Ginecol 1995; 85: 285-9.

Statistical Package for the Social Science (SPSS) for windows. Release 10.0 standard version. User's guide. Chicago: SPSS Inc; 1999. 
Suplido ML, Ong CN. Lead exposure among small-scale battery recyclers, automobile radiator mechanics, and their children in Manila, the Philippines. Environ Res 2000; 82: 231-8.

Symanski E, Hertz-Picciotto I. Blood lead levels in relation to menopause, smoking and pregnancy history. Am J Epidemiol 1995;141: 1047-58.

Tavares T. Avaliação de efeitos das emissões de cádmio e chumbo em Santo Amaro, Bahia. Salvador; 1990. [Tese de Doutorado - Instituto de Quimica da Universidade de São Paulo].

Téllez-Rojo MM, Hernández-Avila M, Gonzáles-Cossio $T$, Romieu Isabelle, Aro A, Palazuelos $E$, et. al. Impact of breastfeeding on the mobilization of lead from bone. Am J Epidemiol 2002; 155: 420-8.

Thatcher RW, Lester ML, McAlaster R, Horst R. Effects of low levels of cadmium and lead on cognitive funtioning in children. Arch Environ Health 1982; 37: 159-66.

Torres-Sánchez L, Berkowitz G, López-Carrillo L, Torres-Arreola L, Rios C, LópezCervantes M. Intrauterine lead exposure and preterm birth. Environ Res 1999; 81: 297 301.

Trombini TV, Pedroso CG, Ponce D, Almeida AA, Gordinho AF. Developmental lead exposure in rats: is a behavioral sequel extend at F2 geration?. Pharmacol Biochem Behav 2001; 68: 743-51.

Troster EJ. Exposição plümblica em um grupo de gestantes e de recém-nascidos na Grande São Paulo. São Paulo; 1986. [Dissertação de Mestrado - Faculdade de Medicina da Universidade de São Paulo].

Vanzetti $G$. An azide-methemoglobin method for hemoglobin determination in blood. $J$ Lab Clin Med 1996; 67: 116-26. 
Watson WS, Morrison J, Bethel MI, Baldwin NM, Lyon DT, Dobson H. Food iron and lead absorption in humans. Am J Clin Nutr 1986; 44: 248-56.

Wedeen RP, Ty A, Favata EA, Jones KW. Clinical application of in vivo tibial K-XRF for monitoring lead stores. Arch Environ Health 1995; 50: 355-61.

[WHO] World Health Organization. Inorganic lead. Geneva; 1995. (WHO Environmental Health Criteria, 165)

[WHO] World Health Organization. Obesity: prevention and managing the global epidemic- report of a WHO consultation on obesity. Geneva; 3-5 June 1998.

Wright RO, Tsaih SW, Schwartz J, Wright RJ, Hu H. Association between iron deficiency and blood lead level in a longitudinal analysis of children followed in an urban primary care clinic. J Pediatr 2003; 142:9-14. 
ANEXO 1

Formulário de Entrevista 
FACULDADE DE SAÚDE PÚBLICA - USP

A RELAÇĀO DA CONCENTRAÇĀO DE CHUMBO NOS SANGUES MATERNO E DO CORDÃO UMBILICAL

\section{FORMULÁRIO DE ENTREVISTA}

(8) não se aplica

(9) não sabe a resposta

PAR PARTURIENTE RECÉM-NASCIDO №

Data da admissão I I

Data da entrevista

№ Registro no hospital

Tipo de atendimento

\section{A.DADOS PESSOAIS DA PARTURIENTE}

1. Nome:

2.Endereço:

Ponto de referência:

Telefone:

3. Data de nascimento:

4. Idade:

5. Estado civil: (0) solteira (1) casada (2) viúva (3) separada/divorciada

6. Com quem você mora atualmente?

(0) sozinha (1) companheiro (2) pais (3) tios

7. Nivel educacional:

\begin{tabular}{|l|c|l|c|l|c|c|}
\hline & $\begin{array}{l}\text { Primário } \\
\text { Incompleto }\end{array}$ & $\begin{array}{l}\text { Primário } \\
\text { Completo } \\
(4 \text { anos })\end{array}$ & $\begin{array}{l}\text { Ginásio } \\
\text { Incompleto }\end{array}$ & $\begin{array}{l}\text { Ginásio } \\
\text { Completo } \\
(8 \text { anos })\end{array}$ & $\begin{array}{l}\text { Colegial } \\
\text { Incompleto }\end{array}$ & $\begin{array}{l}\text { Colegial } \\
\text { Completo } \\
(11 \text { anos })\end{array}$ \\
\hline Parturiente & 1 & 2 & 3 & 4 & 5 & 6 \\
\hline Companheiro & 1 & 2 & 3 & 4 & 5 & 6 \\
\hline
\end{tabular}

\begin{tabular}{|c|c|c|c|c|c|}
\hline & \multirow{2}{*}{$\begin{array}{l}\text { Universitário } \\
\text { Incompleto }\end{array}$} & \multirow{2}{*}{$\begin{array}{l}\text { Universitário } \\
\text { completo }\end{array}$} & \multicolumn{2}{|c|}{ Nunca freqüentou a escola } & \multirow[t]{2}{*}{ NS } \\
\hline & & & $\begin{array}{l}\text { Não sabe ler } \\
\text { nem escrever }\end{array}$ & $\begin{array}{l}\text { Sabe ler e } \\
\text { escrever }\end{array}$ & \\
\hline Parturiente & 7 & 10 & 11 & 12 & 9 \\
\hline Companheiro & 7 & 10 & 11 & 12 & 9 \\
\hline \multicolumn{5}{|c|}{$\begin{array}{l}\text { 8. Você trabalha? } \\
\text { (0) Sim (1) Não }\end{array}$} & \\
\hline \multicolumn{5}{|c|}{$\begin{array}{l}\text { 9. Em que você trabalha? } \\
\text { (0) dona de casa (1) empregada doméstica ( } 2 \text { ) conta própria (3) outros } \\
\text { especificar }\end{array}$} & \\
\hline
\end{tabular}


10. Peso atual da parturiente

11. Altura

12. Indice de Massa Corporal

13. Número de gestações (incluindo a atual)

14. Número de filhos nascidos vivos

15. Número de natimortos

16. Número de abortos

17. Número de filhos nascidos vivos que morreram com menos de 1 ano

18. Número de filhos prematuros

19. Número de filhos nascidos à termo com baixo peso

20. Peso do recém-nascido

21. Comprimento do recém-nascido

22. Sexo do recém-nascido (0) masculino (1) feminino

\section{MEDICAMENTOS}

23. Você tomou algum medicamento nesta gravidez ? (0) $\operatorname{Sim}(1)$ Não

24. Qual (is) o (os) nome (s) do (s) medicamento (s) ?

1.medicamento

2. Medicamento

Se a gestante não lembrar os nomes, perguntar que tipo de medicamento tomou?

(0) suplementos de $\mathrm{Ca}(1)$ suplementos de $\mathrm{Fe}(3)$ outros

1 medicamento 2 medicamento

\section{RENDA FAMILIAR}

25. Renda familiar mensal: reais

Salários minimos (SM): $(0) \leq 1 \mathrm{SM}(1)>1 \mathrm{e} \leq 2 \mathrm{SM}(2)>2 \mathrm{e} \leq 5 \mathrm{SM}(3)>5$ $e \leq 10 \mathrm{SM}(4)>10 \mathrm{SM}$

26. Número de pessoas que contribuem

27. Numero de pessoas da casa 
28. A família tem outras fontes de renda (pensão, aluguel, etc.)?(0) Sim

(1)Nāo

29. De quanto é? reais

Salários minimos (SM): (0) $\leq 1 \mathrm{SM}(1)>1$ e $\leq 2 \mathrm{SM}(2)>2$ e $\leq 5 \mathrm{SM}(3)>5$ $e \leq 10$ SM (4) $>10$ SM

I. CONTROLE DE DOSAGEM BIOQUIMICA DO CHUMBO (Espectrofotometria)

\begin{tabular}{|c|c|c|}
\hline PARÂMETRO & PARTURIENTE & CORDÃO UMBILICAL \\
\hline Chumbo & & \\
\hline
\end{tabular}

II. CONTROLE DE DOSAGENS BIOQUIMICAS DO CHUMBO (LeadCare)

\begin{tabular}{|c|c|c|}
\hline \multicolumn{1}{|c|}{ PARÂMETRO } & PARTURIENTE & CORDÃO UMBILICAL \\
\hline Chumbo & & \\
\hline
\end{tabular}

III. CONTROLE DE DOSAGEM BIOQUIMICA DA HEMOGLOBINA (HemoCue)

\begin{tabular}{|c|c|c|c|c|}
\hline \multirow{2}{*}{ PARÂMETRO } & \multicolumn{2}{|c|}{ PARTURIENTE } & \multicolumn{2}{c|}{ CORDÃO UMBILICAL } \\
\hline & $1^{\text {a }}$ medida & $2^{\text {a }}$ medida & $1^{\text {a }}$ medida & $2^{\text {a } \text { medida }}$ \\
\hline Hemoglobina $(\mathrm{g} / \mathrm{d} \mathrm{l})$ & & & & \\
\hline
\end{tabular}


ANEXO 2

Questionário de Freqüência Alimentar 


\section{QUESTIONÁRIO DE FREQÜÊ̂NCIA ALIMENTAR}

\begin{tabular}{|c|c|c|c|c|c|c|}
\hline ALIMENTO & $\begin{array}{l}\text { PORÇÁOI } \\
\text { TAMANHO }\end{array}$ & $\begin{array}{c}N^{\circ} \mathrm{DE} \\
\text { PORÇÕES }\end{array}$ & $N^{\circ}$ VEZES & $\begin{array}{l}\text { DIÁRIA } \\
5 \text { a } 7 \times \text { por } \\
\text { semana }\end{array}$ & $\begin{array}{l}\text { SEMANAL } \\
2 \text { a } 4 \text { x por } \\
\text { semana }\end{array}$ & $\begin{array}{c}\text { MENSAL } \\
1 \text { a } 4 \text { x por } \\
\text { mês }\end{array}$ \\
\hline \multicolumn{7}{|l|}{$\begin{array}{l}\text { LEITEE } \\
\text { DERIVADOS }\end{array}$} \\
\hline Leite integral & Copo Americano $(200 \mathrm{ml})$ & & & & & \\
\hline Leite em pó & Colher de Sopa (16 g) & & & & & \\
\hline Manteiga & Ponta de Faca $(2,5 \mathrm{~g})$ & & & & & \\
\hline Queijo & Fatia Média (35 g) & & & & & \\
\hline \multicolumn{7}{|l|}{$\begin{array}{l}\text { CEREAIS, PĀES, } \\
\text { RAİZES E } \\
\text { TUBÉRCULOSS }\end{array}$} \\
\hline Arroz & Colher de Sopa (25 g) & & & & & \\
\hline Macarrão & Pegador $(70 \mathrm{~g})$ & & & & & \\
\hline Pão francês & Unidade $(50 \mathrm{~g})$ & & & & & \\
\hline Pão de milho & Unidade $(60 \mathrm{~g})$ & & & & & \\
\hline Pão de sal & Unidade (5 g) & & & & & \\
\hline $\begin{array}{l}\text { Biscoito de } \\
\text { maicena }\end{array}$ & Unidade (5 g) & & & & & \\
\hline $\begin{array}{l}\text { Biscoito água e } \\
\text { sal }\end{array}$ & Unidade $(7 \mathrm{~g})$ & & & & & \\
\hline $\begin{array}{l}\text { Farinha de } \\
\text { mandioca }\end{array}$ & Colher de Sopa $(8 \mathrm{~g})$ & & & & & \\
\hline Cuscuz de milho & Fatia Média (30 g ) & & & & & \\
\hline Canjica & Fatia Média (30 g) & & & & & \\
\hline Batata doce & Unidade Média $(70 \mathrm{~g})$ & & & & & \\
\hline Batata & Unidade Média $(90 \mathrm{~g})$ & & & & & \\
\hline \multicolumn{7}{|l|}{ LEGUMINOSAS } \\
\hline Feijão carioca & Concha Média (90 g) & & & & & \\
\hline $\begin{array}{l}\text { Feijão carioca } \\
\text { com carne }\end{array}$ & Concha Média (125 g) & & & & & \\
\hline \multicolumn{7}{|l|}{$\begin{array}{l}\text { CARNES, } \\
\text { PESCADOS E } \\
\text { OVOS }\end{array}$} \\
\hline Boi gordo & $\begin{array}{l}1 \text { Bife Médio ou } 4 \text { Cubos } \\
(90 \mathrm{~g})\end{array}$ & & & & & \\
\hline Boi magro & $\begin{array}{l}1 \text { Bife Médio ou } 4 \text { Cubos } \\
(90 \mathrm{~g})\end{array}$ & & & & & \\
\hline Frango sem pele & Filé Médio $(90 \mathrm{~g})$ & & & & & \\
\hline Calabreza & $1 / 2$ Gomo $(60 \mathrm{~g})$ & & & & & \\
\hline Carne de sertão & 4 Cubos $(80 \mathrm{~g})$ & & & & & \\
\hline Curvina & Posta Média $(120 \mathrm{~g})$ & & & & & \\
\hline Ovo & Unidade (50 g) & & & & & \\
\hline
\end{tabular}




\begin{tabular}{|c|c|c|c|c|c|c|}
\hline ALIMENTO & $\begin{array}{l}\text { PORÇÃOI } \\
\text { TAMANHO }\end{array}$ & $\begin{array}{c}N^{\circ} \mathrm{DE} \\
\text { PORÇÕES }\end{array}$ & $N^{\circ}$ VEZES & $\begin{array}{c}\text { DIARIA } \\
5 \text { a } 7 \text { x por } \\
\text { semana }\end{array}$ & $\begin{array}{c}\text { SEMANAL } \\
2 \text { a } 4 \times \text { por } \\
\text { semana }\end{array}$ & $\begin{array}{c}\text { MENSAL } \\
1 \text { a } 4 \times \text { por } \\
\text { mês }\end{array}$ \\
\hline \multicolumn{7}{|l|}{$\begin{array}{l}\text { AÇÚCARES E } \\
\text { DOCES }\end{array}$} \\
\hline Açúcar & Colher de Chá $(5 \mathrm{~g})$ & & & & & \\
\hline Biscoito de coco & Unidade (4 g) & & & & & \\
\hline Biscoito recheado & Unidade (14 g) & & & & & \\
\hline Suco artificial & $\begin{array}{l}\text { Copo de Requeijão ( } 230 \\
\mathrm{ml})\end{array}$ & & & & & \\
\hline Refrigerante & $\begin{array}{l}\text { Copo de Requeijão ( } 230 \\
\mathrm{ml})\end{array}$ & & & & & \\
\hline \multicolumn{7}{|l|}{ FRUTAS } \\
\hline Banana terra & Unidade média (114 g) & & & & & \\
\hline Banana prata & Unidade Média (55 g) & & & & & \\
\hline Laranja & Unidade Média (150 g) & & & & & \\
\hline $\begin{array}{l}\text { Suco cítrico } \\
\text { (laranja, acerola, } \\
\text { limão, maracujá) }\end{array}$ & $\begin{array}{l}\text { Copo de Requeijão (230 } \\
\text { ml) }\end{array}$ & & & & & \\
\hline \multicolumn{7}{|l|}{ HORTALIÇAS } \\
\hline Alface & Folha grande (12 g) & & & & & \\
\hline Abóbora cozida & Colher de Sopa (25 g) & & & & & \\
\hline Cenoura cozida & Colher de Sopa $(20 \mathrm{~g})$ & & & & & \\
\hline Tomate & Unidade Média $(80 \mathrm{~g})$ & & & & & \\
\hline Repolho & Folha $(30 \mathrm{~g})$ & & & & & \\
\hline \multicolumn{7}{|l|}{ OUTROS } \\
\hline Café adoçado & Copo Americano $(200 \mathrm{ml})$ & & & & & \\
\hline Café puro & Xícara de Chá $(250 \mathrm{ml})$ & & & & & \\
\hline Margarina & Ponta de Faca $(2,5 \mathrm{~g})$ & & & & & \\
\hline
\end{tabular}

*Quantas pessoas normalmente fazem as seguintes refeiçōes na sua casa?

Café da manhã pessoas

Lanche da manhã pessoas

Almoço pessoas

Lanche da tarde pessoas

Jantar pessoas 
ANEXO 3

Termo de Consentimento 


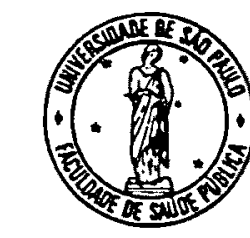

UNIVERSIDADE DE SÃO PAULO

FACULDADE DE SAÚDE PÚBLICA

DEPARTAMENTO DE NUTRIÇÃO

Av. Dr. Arnaldo, 715 - CEP: 01246-904 - São Paulo.

Fone/Fax: 3066-7736 ou 7705/7762/7701 ou 852-6748

Termo de consentimento

Resolução 196/96 - Conselho Nacional de Saúde

$\mathrm{Eu}$,

declaro, para os devidos fins, que concordo em participar e autorizo meu filho recém nascido a participar da pesquisa "A relação da concentração de chumbo nos sangues materno e do cordão umbilical", que tem o objetivo de avaliar a relação da concentração de chumbo nos sangues materno e do cordão umbilical. Eu responderei uma entrevista para fornecer dados importantes para a pesquisa, que serão usados somente para a pesquisa, ficando garantida a privacidade das informações. Permito a coleta, em mim, de $2 \mathrm{ml}$ de sangue venoso antes do parto e $2 \mathrm{ml}$ de sangue do cordão umbilical. Fui esclarecida de que as técnicas utilizadas para os procedimentos de coleta serão feitas tomando-se os cuidados necessários, garantindo a minha segurança e da criança. Foi garantido que qualquer dúvida sobre o estudo será esclarecida pela pesquisadora responsável, sendo assegurado que em qualquer momento do estudo, eu posso retirar o consentimento de participação sem qualquer constrangimento ou prejuízo.

Santo Amaro da Purificação, Bahia, de de 2002

Parturiente

Pesquisadora

Dúvidas ou informações, procurar: Luz Estela Zentner Alva ou Patrícia Helen de Carvalho Rondó. Faculdade de Saúde Pública da Universidade de São PauloAv. Dr. Arnaldo, 715. São Paulo/SP. Tel (011) 852-6748 ou 3066-7701-ramal 31. 
ANEXO 4

Carta da Comissão de Ética 


\section{UNIVERSIDADE DE SÃO PAULO \\ FACULDADE DE SAÚDE PÜBLICA \\ COMITE DE ETICA EM PESQUISA-COEP}

Av. Dr. Arnaldo, 715 - Cerqueira César

São Paulo-SP - CEP: 01246-904

Telefone: (0xx11) 3066-7779 - e-mail: mdgracas@usp.br

Of.COEP/175/01

31 de agosto de 2001

Pelo presente, informo que o Comitê de Ética em Pesquisa da Faculdade de Saúde Pública da Universidade de São Paulo-COEP, analisou e aprovou, de acordo com os requisitos da Resolução CNS/196/96, o Protocolo de Pesquisa n. ${ }^{\circ} 549$, intitulado: “A RELAÇÃO DA CONCENTRAÇÃO DE CHUMBO NOS SANGUES MATERNO E DO CORDÃO UMBILICAL", apresentado pela pesquisadora Luz Estela Zentner Alva.

Atenciosamente,

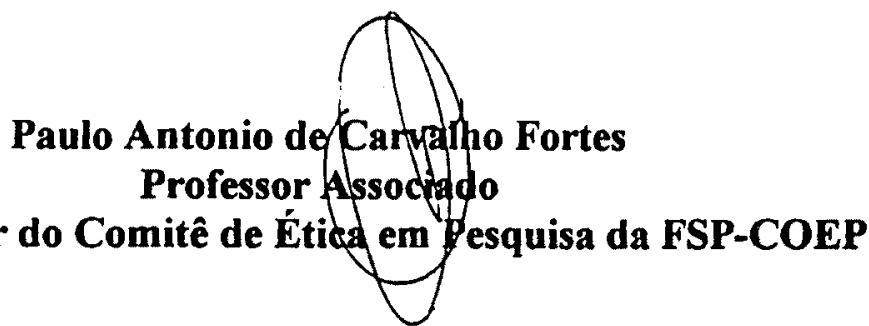

Coordenador do Comitê de Ética em esquisa da FSP-COEP 
ANEXO 5

Gráficos de análises de resíduos 
Análise de resíduos

Modelo final: Chumbo na parturiente

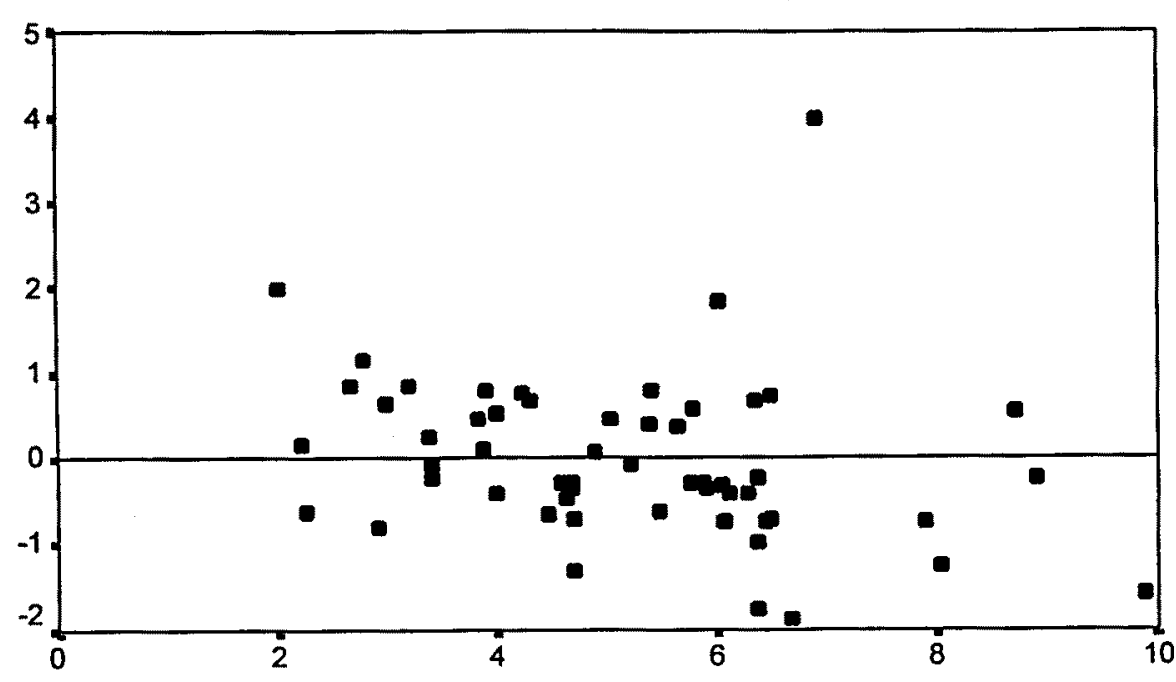

Regression Adjusted (Press) Predicted Value

Análise de resíduos

Modelo final: Chumbo no recém-nascido

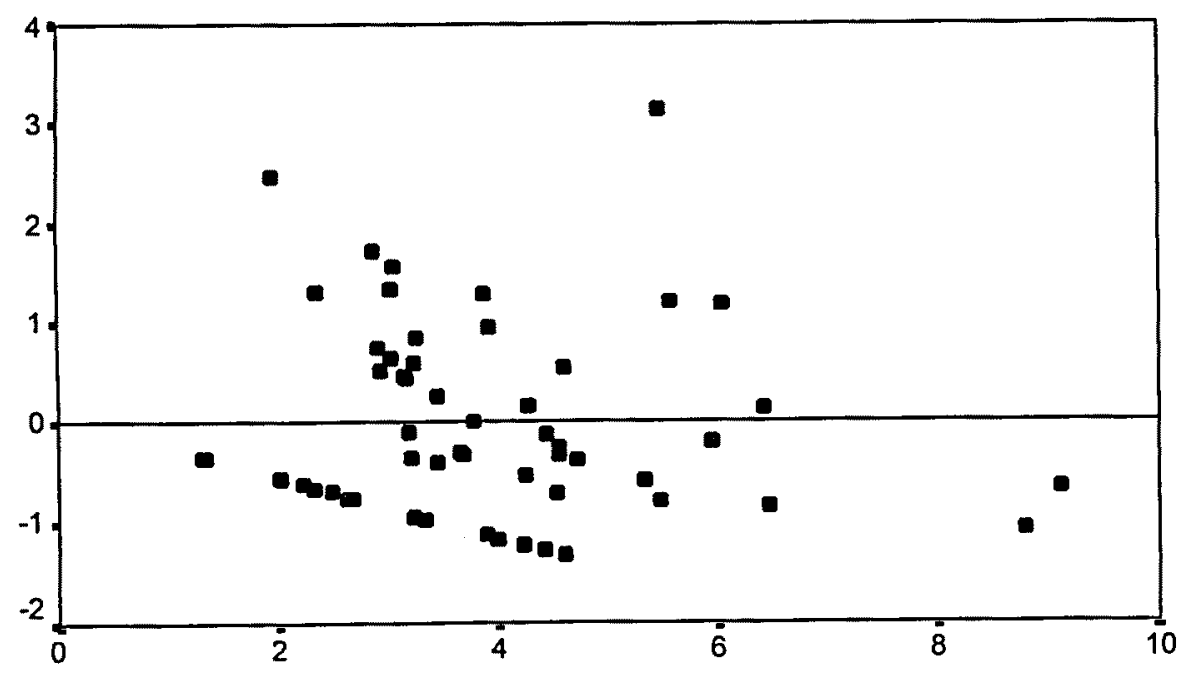

Regression Adjusted (Press) Predicted Value 